CURRENT WATER-RESOURCES ACTIVITIES IN OHIO, 1987

Compiled by Charlene C. Vince

U.S. GEOLOGICAL SURVEY

Open-File Report 87-102

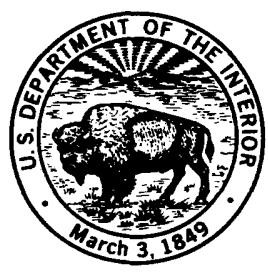

Columbus, Ohio

1987 


\author{
DEPARTMENT OF THE INTERIOR \\ DONALD PAUL HODEL, Secretary \\ U.S. GEOLOGICAL SURVEY \\ Dallas L. Peck, Director
}

For additional information write to:

District Chief

Water Resources Division

U.S. Geological Survey

975 W. Third Avenue

Columbus, Ohio 43212
Copies of this report can be purchased from:

U.S. Geological Survey Books and Open-File Reports Building 41

Box 25425, Federal Center Denver, Colorado 80225 


\section{FOREWORD}

The U.S. Geological Survey, Water Resources Division, has been active in water-resource investigations in ohio for more than 70 years. During that time, volumes of data have been collected, numerous investigations completed, and more than 150 reports published on various aspects of Ohio's water resources. Many changes have taken place in the Geological survey and the Water Resources Division since its formation in 1879 , but our mission remains firm--"to provide the hydrologic information and understanding needed for the optimum utilization and management of the Nation's water resources for the overall benefit of the people of the United States." As the water resources of Ohio become increasingly important to its economy and quality of life, the Ohio District's role as an unbiased water resource investigation and data-collection agency also becomes increasingly important.

Over the years the District's programs have reflected the needs of the people and priority issues of the times. We have evolved from the early days of ground- and surface-water reconnaissance studies into flood and low-flow studies, projects associated with energy production, and finally, into studies relating to toxic- and hazardous-waste disposal. Through all of this, the district has continued to expend a considerable amount of its resources in collecting and disseminating basic data on surface water, ground water, water quality, and sediment.

Our present program centers on four areas: Basic hydrologic data collection, surface-water modeling, coal-mine reclamation, and ground-water assessment. In all of the above areas, chemical quality of the resource is an important factor. In fact, I feel that water quality will become the overriding concern in all water-resource investigations through the remainder of the 1980's and into the 1990's. The use of computers and digital modeling will continue to be an integral part of all investigations.

The next few years promise a growth of new projects directed toward contamination of ground and surface waters and associated effects on hydrologic systems. To meet this need, the district will correspondingly increase its technical expertise in the fields of geohydrology and organic geochemistry. I look forward to the U.S. Geological Survey's active role in these activities and a continuing relationship with state, county, local, and other Federal agencies in studying the water-resource issues of ohio.

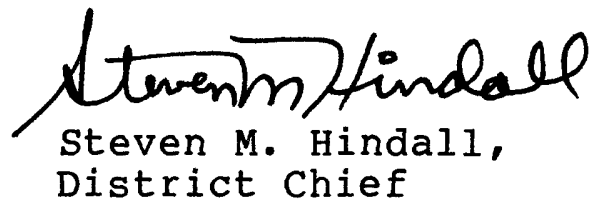

iii 
CONTENTS

Page

Foreword

Origin of the U.S. Geological Survey- 1

Basic mission and program of the Water Resources

Division--

Organization and activities of the ohio District---- 3

Organization- 3

Types of funding and cooperating agencies---_--- 4

Public-information and public-service activities- 7

Summary of water conditions in ohio- 7

Information contained in this report

Other information available 10

Current projects-- 10

Surface-water stations for which records are published----- 33

Ground-water stations for which records are published----- 38

Selected references on Ohio hydrology- 45

\section{ILLUSTRATION}

Figure 1. Map showing average discharge of principal streams in Ohio 


\title{
CURRENT WATER-RESOURCES ACTIVITIES IN OHIO, 1987
}

\author{
Compiled by Charlene C. Vince
}

\section{ABSTRACT}

The mission of the U.S. Geological Survey's Water Resources Division is to provide the hydrologic information and understanding needed for the optimum utilization and management of the Nation's water resources for the overall benefit of the United States. This report summarizes the Division's program in Ohio in 1987 .

The work of the Ohio District is carried out through the District office in Columbus and a field office in New Philadelphia. Collection of basic data needed for continuing determination and evaluation of the quantity, quality, and use of Ohio's water resources is the responsibility of the District's Hydrologic Surveillance Section. The Hydrologic Investigations section conducts analytical and interpretive water-resource appraisals describing the occurrence, availability, and the physical, chemical, and biological characteristics of surface and ground water.

In addition to introductory material describing the structure of the Ohio District, information is presented on current projects, sites at which basic surface- and ground-water data are collected, and reports on ohio's water resources published by the U.S. Geological Survey and cooperating agencies.

\section{INTRODUCTION}

\section{Origin of the U.S. Geological Survey}

The U.S. Geological Survey was established by an act of Congress on March 3, 1879, to provide a permanent Federal agency to conduct the systematic and scientific "classification of the public lands, and examination of the geological structure, mineral resources, and products of national domain." An integral part of that original mission includes publishing and disseminating the earth-science information needed to understand, to plan the use of, and to manage the Nation's energy, land, mineral, and water resources.

Since 1879, the research and fact-finding role of the survey has grown and been modified to meet the changing needs of the Nation it serves. As part of that evolution, the survey has become the Federal Government's largest earth-science research 
agency, the Nation's largest civilian mapmaking agency, the primary source of data on the Nation's surface- and ground-water resources, and the employer of the largest number of professional earth scientists. Today's programs serve a diversity of needs and users. Programs include:

- Conducting detailed assessments of the energy and mineral potential of the Nation's land and offshore areas.

Investigating and issuing warnings of earthquakes, volcanic eruptions, landslides, and other geologic and hydrologic hazards.

- Conducting research on the geologic structure of the Nation.

Studying the geologic features, structure, processes, and history of the other planets of our solar system.

- Conducting topographic surveys of the Nation and preparing topographic and thematic maps and related cartographic products.

- Developing and producing digital cartographic data bases and products.

- Collecting data on a routine basis to determine the quantity, quality, and use of surface and ground water.

- Conducting water-resource appraisals in order to describe the consequences of alternative plans for developing land and water resources.

- Conducting research in hydraulics and hydrology, and coordinating all Federal water-data acquisition.

- Using remotely sensed data to develop new cartographic, geologic, and hydrologic research techniques for natural resources planning and management.

- Providing earth-science information through an extensive publications program and a network of public access points.

Along with its continuing commitment to meet the growing and changing earth-science needs of the Nation, the survey remains dedicated to its original mission to collect, analyze, interpret, publish, and disseminate information about the natural resources of the Nation--providing "Earth Science in the Public Service."

\section{Basic Mission and Program of the Water Resources Division}

The mission of the Water Resources Division is to provide the hydrologic information and understanding needed for the optimum utilization and management of the Nation's water resources for the overall benefit of the people of the United States. 
This is accomplished, in large part, through cooperation with other Federal and non-Federal agencies, by:

- Collecting, on a systematic basis, data needed for the continuing determination and evaluation of the quantity, quality, and use of the Nation's water resources.

- Conducting analytical and interpretive water-resource appraisals describing the occurrence, availability, and the physical, chemical, and biological characteristics of surface and ground water.

- Conducting supportive basic and problem-oriented research in hydraulics, hydrology, and related fields of science to improve the scientific basis for investigations and measurement techniques and to understand hydrologic systems sufficiently well to quantitatively predict their response to stress, either natural or manmade.

- Disseminating the water data and the results of these investigations and research through reports, maps, computerized information services, and other forms of public releases.

- Coordinating the activities of Federal agencies in the acquisition of water data for streams, lakes, reservoirs, estuaries, and ground waters.

- Providing scientific and technical assistance in hydrologic fields to other Federal, State, and local agencies, to licensees of the Federal Power Commission, and to international agencies on behalf of the Department of state.

- Administering the provisions of the Water Resources Research Act of 1984, which include the state water Resources Research Institutes and the Research Grants and Contracts Programs.

- Supporting the provisions of the National Environmental Policy Act of 1969 and managing the Geological Survey conduct of natural resources surveys in response to the Comprehensive Environmental Response, Compensation, and Liability Act (Superfund Act) of 1980.

\section{Organization and Activities of the Ohio District}

\section{Organization}

The Ohio District is part of the U.S. Department of the Interior, Geological Survey, Water Resources Division. There are a total of 42 districts throughout the country located in each individual state, with the exception of four districts encompassing two or more states. 
The Ohio District is comprised of the district office in Columbus and a field office in New Philadelphia. There are two major sections in the district office--Hydrologic Investigations and Hydrologic Surveillance. The New Philadelphia field office is part of the Hydrologic Surveillance section.

Steven M. Hindall, District Chief, is responsible for the overall operation and management of the district, and is assisted by Section Chiefs Richard V. Swisshelm, Jr., and Harold L. Shindel. To carry out the diversity of tasks in support of its varied program, the Ohio District's additional 45-member staff consists of hydrologists, hydrologic technicians, and other administrative, clerical, and support personnel.

The chart on page 6 depicts the organization of the Ohio District and explains the functions of the individual sections and units within those sections.

\section{Types of Funding and Cooperating Agencies}

Funds to support the work performed by the Ohio District, Water Resources Division, are derived from three principal sources:

- Federal Program--Funds for the Federal Program are appropriated by the Congress, and are specifically identified in the annual Geological Survey budget. These funds are used to support research, data collection, high-priority topical programs including energy-related programs, the coordination of all Federal programs related to collection of water data, and internal support services.

Federal-State Cooperative Program--Federal funds are appropriated by the Congress and used to match those furnished by state and other tax-supported agencies on a 50-50 basis. These funds funds are used for a variety of hydrologic data-collection activities and water-resources investigations in which the water Resources Division represents the national responsibilities and the cooperating agencies represent state and local interests.

- Other Federal Agencies (OFA) Program--In this program, the funds are transferred to the Geological Survey as reimbursement for work performed at the request of another Federal agency. 
The Ohio District's 1987 Fiscal Year programs; agencies that had signed cooperative agreements as of January 1, 1987; funds allocated; and percentages of total budget are listed by category below:

Federal Program................... \$ 196,000

Federal-State Cooperative Program..... $1,796,000$

Ohio Department of Natural Resources

Division of Water

Division of Reclamation

Division of Natural Areas \& Preserves

Ohio Department of Transportation

Ohio Environmental Protection Agency

Miami Conservancy District

Williams County

City of Columbus

City of Northwood

City of Akron

Geauga County

Lucas County

Sandusky County

wood County

Ross County

Seneca Soil \& Water District (Heidelberg College) (Heidelberg College)

City of Canton

City of Toledo

City of Fremont

other Federal Agencies Program..........

540,000

U.S. Army Corps of Engineers

Federal Emergency Management Agency

U.S. Department of Interior (OSM)

TOTAL.

$\$ 2,532,000$ 

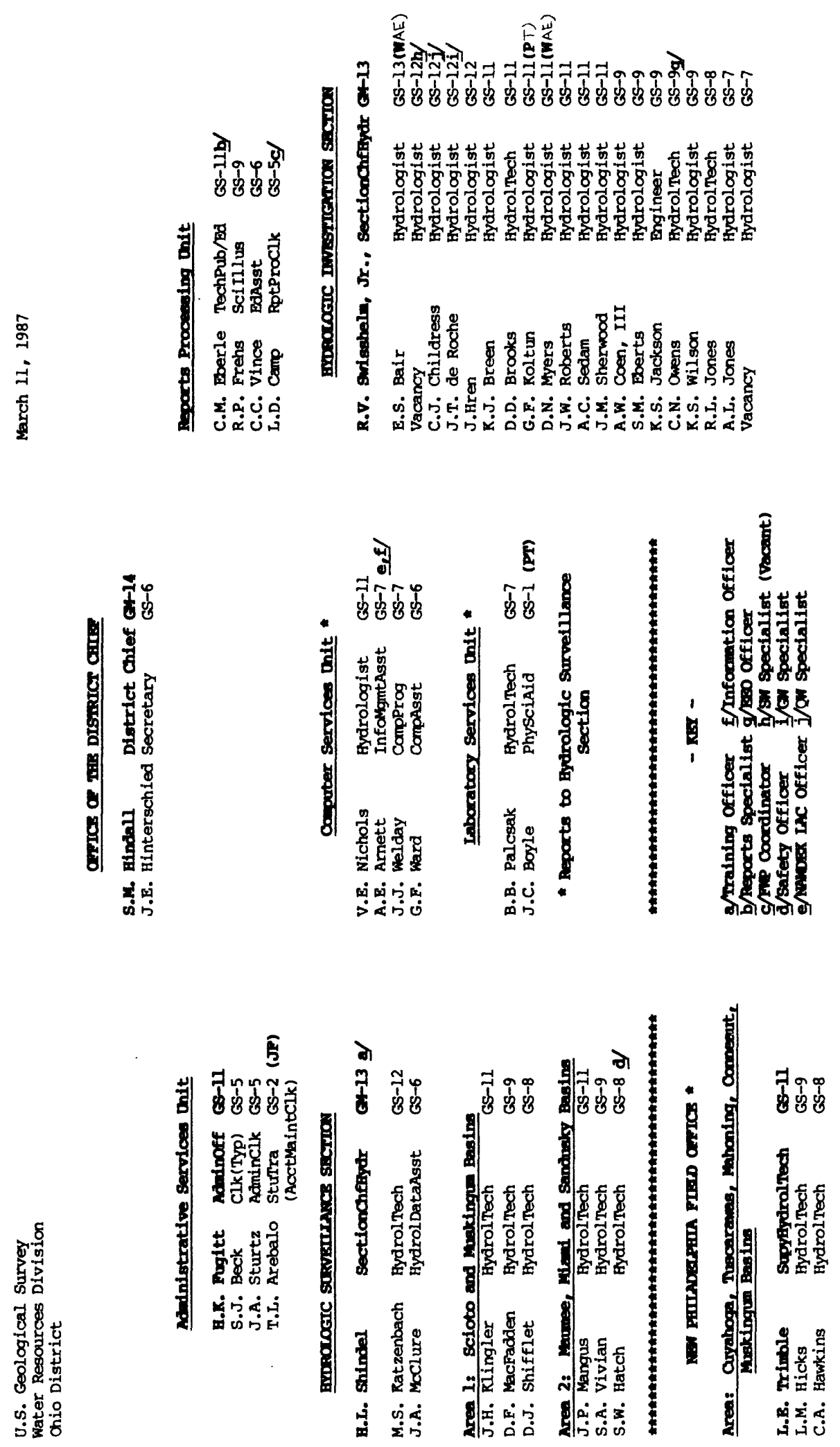
Public-Information and Public-Service Activities

The activities of the Ohio district staff are not confined to project work. Much of the daily activity of the staff is devoted to answering requests from landowners, public officials, and business concerns on a wide range of hydrologic and geologic topics. For example, the ohio district spent approximately 350 hours answering nearly 700 telephone and mail inquiries during 1986 .

District personnel also are involved in education. Staff hydrologists and hydrologic technicians have served as instructors and guest lecturers for water-resources courses at ohio state University, Ohio University, and Central State University. The district also has sponsored seminars and information-exchange meetings with themes ranging from well design to political and social water-resources issues in Ohio.

Equally important is the involvement of district staff in work groups, committees, and task forces of professional societies and other government agencies. Among these groups are:

Technical Committee and Toxic Strategy Subcommittee of the Ohio River Valley water Sanitation Commission (ORSANCO).

- Public Advisory Groups and the Phosphorus-Reduction Task Force of the Ohio Environmental Protection Agency.

- Program Review Panel for the Ohio State University Water Resources Center.

- Steering Committee for the Ohio Water Seminar Luncheon Series.

- Board of Directors of the Ohio Lake Management Society.

- The Ohio State University Student Chapter of the American Society of Civil Engineers (advisory role as Student Contact Member).

\section{Summary of Water Conditions in Ohio}

The availability of water has been an important factor in Ohio's development. Ohio's principal streams (fig. 1) were the settlers' first avenues of transportation and their first sources of power for manufacturing. Shallow, hand-dug wells provided water to a growing farm population. The construction of canals beginning in 1825 continued to encourage the growth of cities and industries and stimulate agricultural production. Today, Ohio is still characterized by a diverse economy in which water resources play a vital part. 


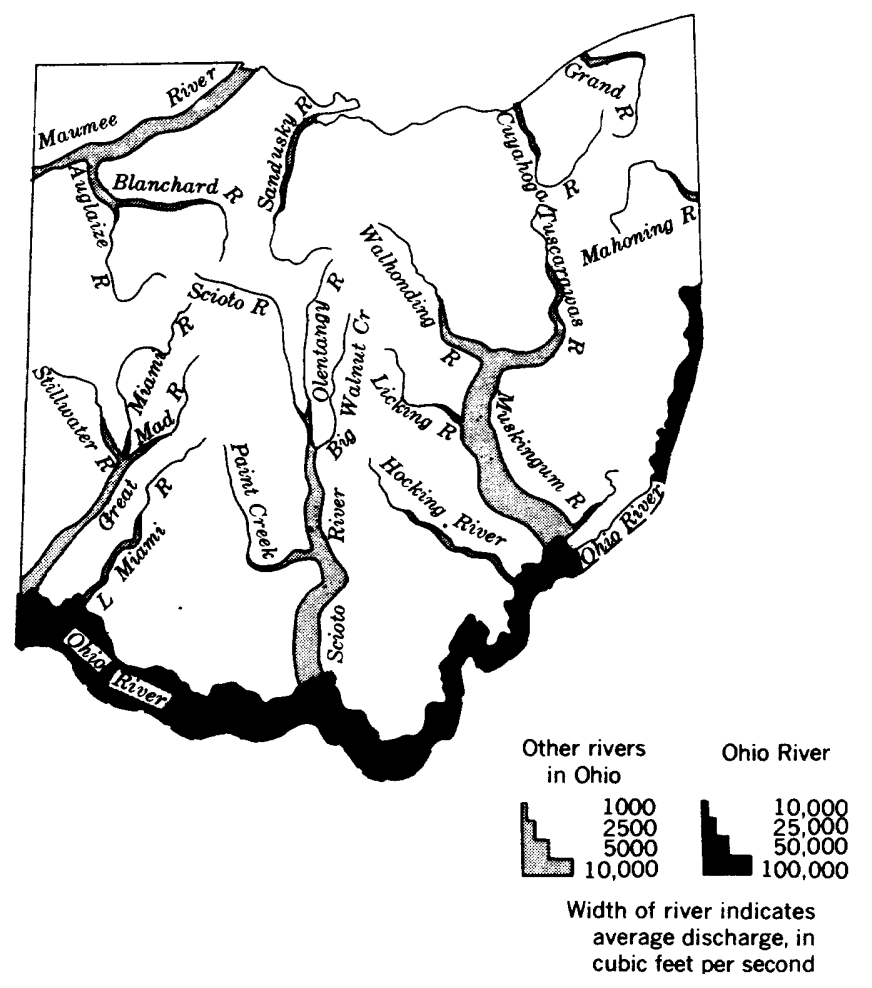

Figure 1.--Average discharge of principal streams in Ohio.

Ohio receives about 38 inches of precipitation annually. About 10 inches runs off immediately, 2 inches is retained at or near the surface and evaporates or transpires, and 26 inches enters the ground. Of the 26 inches that enters the ground, 20 inches is retained in the unsaturated zone and is later lost by evapotranspiration. The remaining 6 inches reaches the water table. Of this 6 inches, 2 inches is eventually discharged to streams, and and the rest is lost by evapotranspiration or consumptive use.

Ohio's water problems tend to be localized. Generally, these problems involve excess water (flooding or poor drainage) or water quality.

Ohio has serious local flooding nearly every year. Most Ohio floods are either flash floods resulting from intense summer thunderstorms or large-stream floods resulting from a combination of rain and snowmelt. Accelerated erosion of bare ground and streambanks and deposition of sediment in stream channels, culverts, and drainage ditches are negative side effects of flooding. Nine projects are active in the Ohio District in 1987 that directly or indirectly contribute to our knowledge of flooding and (or) related sedimentation problems in the state. 
The focus of concern about Ohio's water quality in recent years has been on waste disposal and its effects on ground-water quality. Despite the predominance of surface water in terms of total withdrawal, the importance of ground water to Ohio cannot be overlooked. Nearly 80 percent of the public water-supply systems in the state depend to some extent on ground water as a source. of the ten ground-water projects active in the Ohio District in 1987, two deal specifically with waste-disposal sites. Both are scientific studies to describe local ground-water levels and flow and to provide baseline water-quality data near the sites. (The other eight ground-water projects are resource appraisals.)

\section{INFORMATION CONTAINED IN THIS REPORT}

Information is presented in the remainder of this report in four parts: (1) A listing and brief description of current projects, (2) a listing of surface-water hydrologic data stations, (3) a listing of ground-water hydrologic data stations, and (4) selected references on Ohio hydrology. The first part contains information on the status of all projects in which there has been activity during 1987. Further information concerning project activities is available from the project leader or from Richard V. Swisshelm, Jr., Chief, Hydrologic Investigations Section. The second and third parts contain tables showing station numbers, station names, and types of data collected. Further information on statewide station activities, unpublished records, or provisional data prior to publication is available from Harold L. Shindel, Chief, Hydrologic Surveillance Section. The fourth part is a selected list of reports issued by the U.S. Geological survey and its cooperating agencies concerning hydrologic investigations in ohio. Further information on these reports is available from Ann E. Arnett, Information Officer for the Ohio district.

These contact people can be reached at:

District Office
Water Resources Division
U.S. Geological Survey
975 W. Third Avenue
Columbus, OH 43212
(614) 469-5553

Information about data-collection activities in northeastern Ohio also can be obtained by contacting:

Lowell Trimble

New Philadelphia Field office

Water Resources Division

U.S. Geological Survey

551 Wabash Avenue, P.0. Box 272

New Philadelphia, OH 44663

(216) 343-2343 


\section{OTHER INFORMATION AVAILABLE}

The U.S. Geological Survey publishes an annual series of reports titled "Water Resources Data--Ohio," in which the hydrologic data collected during each water year are presented. Information about these reports and how co obtain them is available from the district office at the address and phone number given above.

Flood-prone-area maps for selected parts of ohio also are available from the district office. These maps were prepared in cooperation with the U.S. Department of Housing and Urban Development, Federal Insurance Administration, to serve as guides for public agencies and private citizens concerned with present and future land development. The maps were prepared on standard 7-1/2 minute topographic quadrangles, and show the approximate area subject to inundation by a 100-year flood.

\section{CURRENT PROJECTS}

The project descriptions that follow show the project number, title, period of the project, cooperating agencies, project leader, purpose of the project, and progress and significant results. 
Period of Project:

Continuous since October 1915

Project Leader:

Harold L. Shindel

\section{Cooperators:}

Ohio Department of Natural Resources

City of Columbus

Miami Conservancy District

Ohio Environmental Protection Agency

City of Canton

U.S. Army Corps of Engineers

Seneca Soil and Water

District

Ross County

City of Fremont

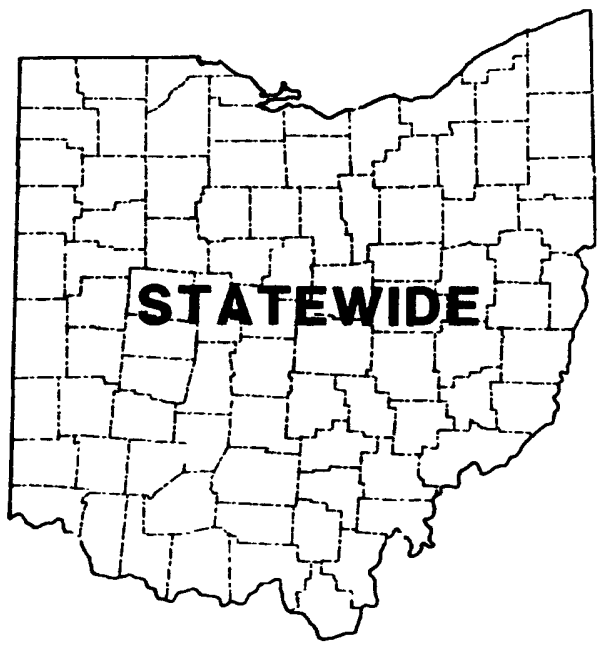

Purpose: To provide a surface-water data base through collection, analysis, and publication of records for gaging stations and selected sites along streams, lakes, and reservoirs throughout Ohio. The gaging-station network is operated in cooperation with other Federal, State, and local agencies. The surface-water data base provides information for research purposes of surveillance, planning, design, hazards warning, accounting systems, operation, and management in various water-related fields.

Progress and significant results: Field data were collected on schedule and prepared for publication (1986 water year). Network maintenance was continued, including modernization equipment in places to improve record quality. Modifications to the network, such as additions or deletions of stations or data-collecting activity, were made in response to program's needs. 
GROUND-WATER STATIONS

$(\mathrm{OH} 002)$

Period of Project:

Continuous since January 1938

Project Leader:

Stephen A. Vivian

Cooperator:

Ohio Department of Natural

Resources

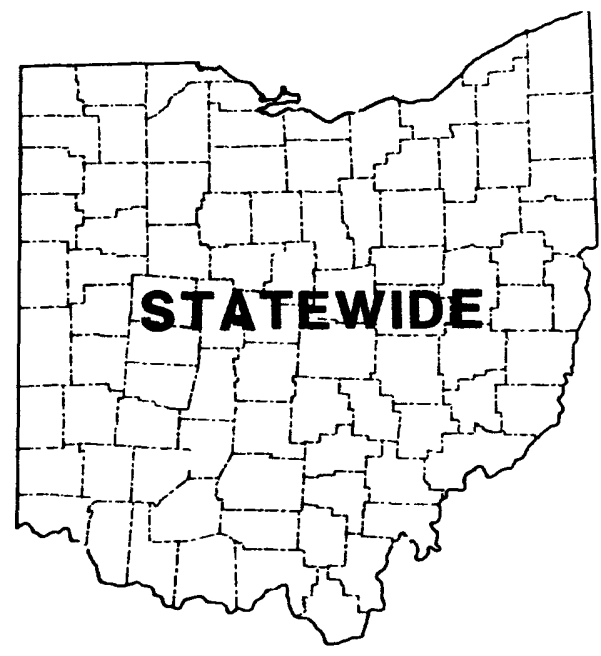

Purpose: To observe the effects on ground-water quantity and quality exerted by such factors as climatic variations and withdrawal patterns. Water-level data are collected to provide a data base against which short- and long-term fluctuations can be compared for proper planning and management.

Progress and significant results: Field data were collected and processed on schedule. Network currently consists of 10 sites with continuous recorders, 13 sites with periodic measurements, and 89 state-operated sites with continuous recorders. 
Period of Project:

Continuous since January 1946

Project Leader:

Betty B. Palcsak

Cooperators:

Miami Conservancy District

Ohio Environmental Protection Agency

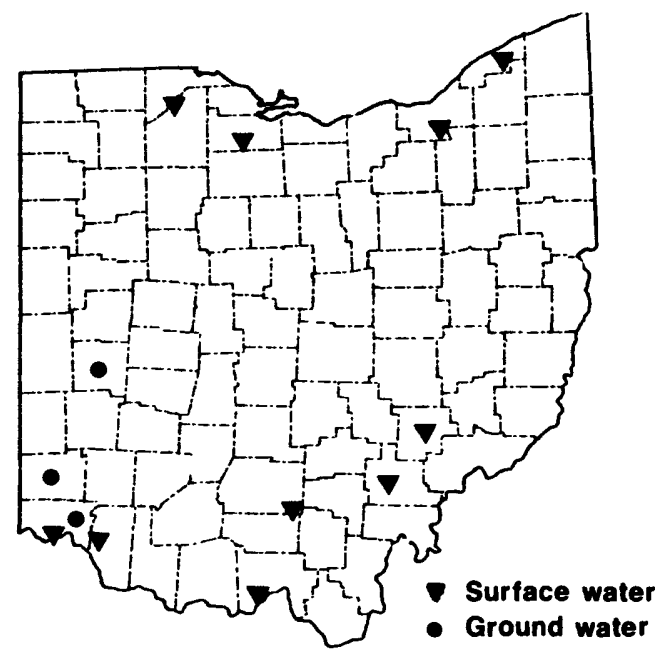

Purpose: To collect, analyze, and publish water-quality records for selected sites in Ohio in cooperation with State and local agencies. The records contribute to a national waterquality data base requisite to nationwide and regional planning and action programs.

Progress and significant results: Stations operated by the U.S. Geological Survey consisted of nine NASQAN stations and one Benchmark station in the water-quality network in the 1986 water year. Four Miami Conservancy District ground-water sites also were sampled. The Geological Survey collects a water sample at the NASQAN sites for the Ohio Environmental Protection Agency for the determination of chemical oxygen demand. 
Period of Project:

Continuous since July 1970

Project Leader:

Jesse $\mathrm{H}$. Klingler

Cooperator:

Ohio Department of Natural Resources

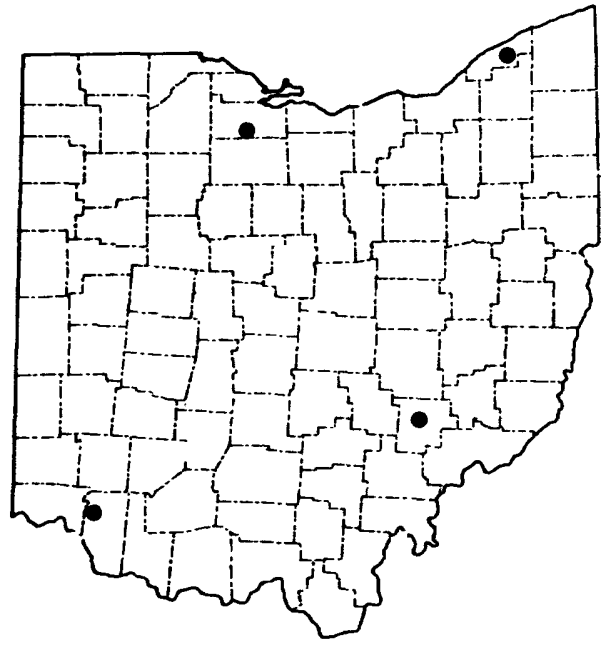

Purpose: To provide a data base needed to assess sedimentation characteristics of drainage areas required for planning and management of State and Federal programs. The data also are needed to evaluate effectiveness of Ohio House Bill 513, which concerns the abatement of sediment pollution in agricultural and urban situations.

Progress and significant results: A network of four daily sediment stations representative of Ohio's major physiographic provinces is being operated to provide spatial and temporal averages of concentration, discharge, and particle-size distribution of suspended sediment carried by major streams. Suspendedsediment data also were collected from finite-duration studies in selected aricultural, mined, and urban areas. All 1986 data were collected on schedule. 
FLOOD INVESTIGATIONS

(OH006)

Period of Project:

March 1984 (reestablished)

through October 1987.

\section{Project Leader:}

$\mathrm{K}$. Scott Jackson

\section{Cooperator:}

Federal Emergency Management

Agency (FEMA)

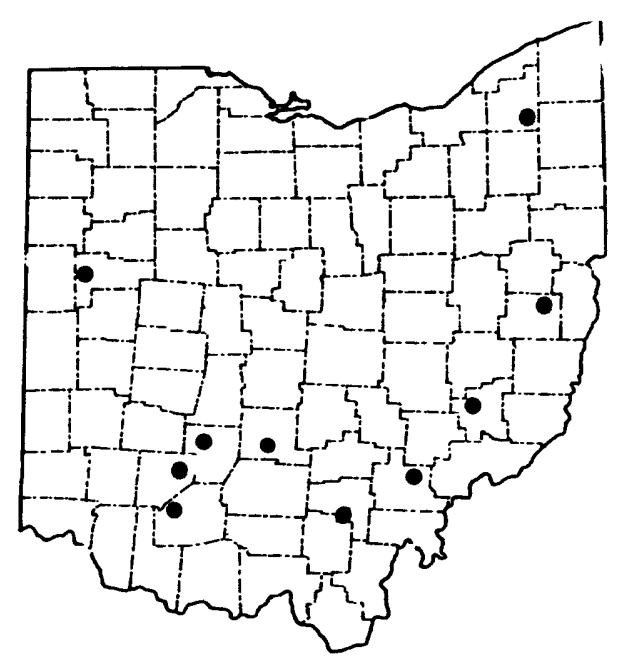

Purpose: The National Flood Insurance Act of 1968 and the Flood Disaster Protection Act of 1973 provide for the operation of a flood insurance program. The Federal Emergency Management Agency (FEMA) needs flood studies in selected areas to determine applicable flood insurance premium rates.

The purpose of this project is to conduct the necessary hydrologic and hydraulic evaluations and studies of areas assigned by FEMA and to present the results in an appropriate format.

Progress and significant results: Work has been completed on FEMA-FIA Type 15 flood-insurance studies at Crooksville, Perry County, and London, Madison County, Ohio. Meetings were held with FEMA, State, and community officials to determine time required and costs of 10 Limited Detail Studies. FEMA has funded these 10 Limited Detail Studies, and they are now in progress. The areas to be studied are: St. Marys, Auglaize County; Darbyville, Pickaway County; Jewett, Harrison County; Amesville, Athens County; Middlefield, Geauga County; Jeffersonville, Fayette County; Belle Valley, Noble County; Sabina, Clinton County; Lynchburg, Highland County; and Hamden, Vinton County. 
Period of Project:

Continuous since October 1977

Project Leader:

Vance E. Nichols

Cooperator:

Ohio Department of Natural

Resources

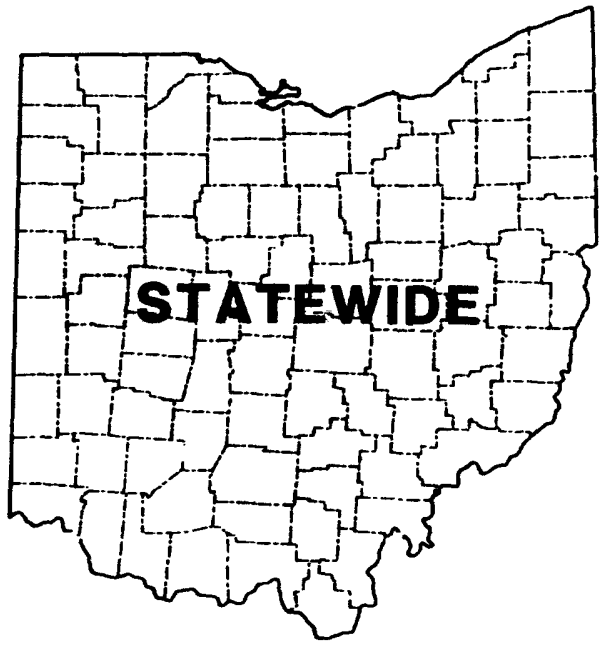

Purpose: To establish an effective and coordinated program for collecting, storing, accessing, and disseminating water-use data. The data are organized to be compatible with a national data base for water use. In Ohio, there is a demonstrated need for local and statewide water-use information that is consistent with regard to definitions, standards, and methods of presentation.

Progress and significant results: A U.S. Geological Survey Fact Sheet, "Water Withdrawals by Thermoelectric Power Plants and Public Water Suppliers in Ohio, 1982," was published. Publicwater-supply and commercial data were entered into the preliminary version of a State Water-Use data base. 
Period of Project:

Continuous since June 1963

Project Leader:

G. F. Koltun

\section{Cooperator:}

Ohio Department of Transportation

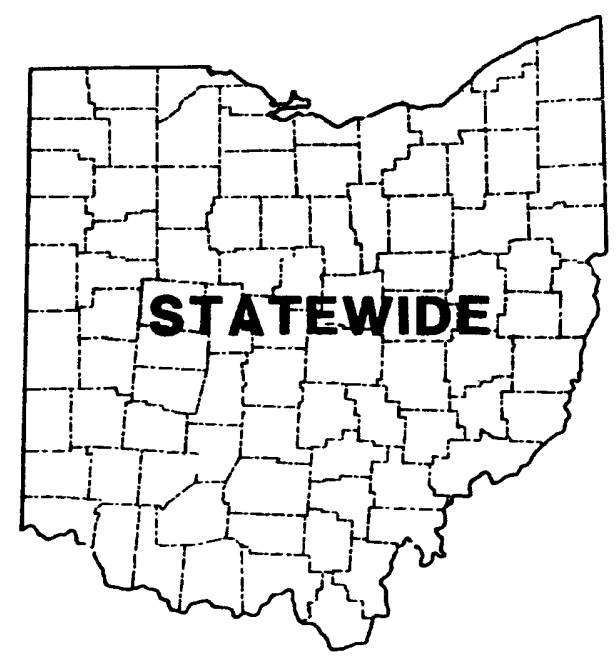

Purpose: To evaluate the hydraulic effects of proposed or existing bridges and highway fills at selected locations. Such structures decrease the capacity of river valleys for conveying floodwaters, and in turn may cause backwater and excessive upstream flooding. This project also provides information to highway engineers on miscellaneous hydrologic topics related to the design or maintenance of highway properties.

Progress and significant results: Equipment was installed to monitor the relative effectiveness of a conventional sand and gravel fill highway drainage system and a drainage mat highway drainage system. The drainage mat system responded quicker after rain events and with more peaked discharges than the conventional sand and gravel fill early in the monitoring period; however, recent results suggest that conventional drain now provides quicker, more peaked response. Bucket surveys were performed in extreme northeastern and southern ohio as a result of heavy rains that damaged major highways. 
INVESTIGATION AND ANALYSIS OF FLOODS FROM SMALL NORTHWESTERN, STRIP-MINED, AND FORESTED DRAINAGE BASINS IN OHIO (OH034)

Period of Project: July 1977 to June 1988

Project Leader:

John W. Roberts

Cooperator:

Ohio Department of Transportation

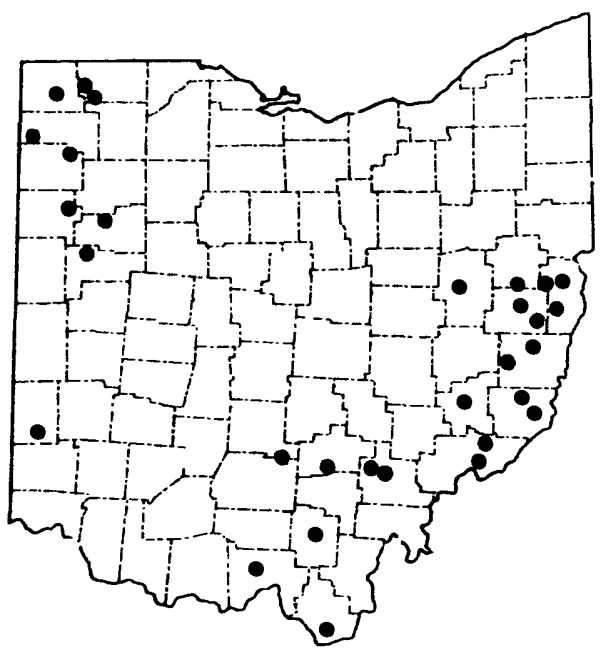

Purpose: To determine flood characteristics for 30 small basins in reclaimed strip-mined areas, forested areas, and northwestern Ohio. Information is needed for engineering design purposes concerning the degree to which flood flows from small basins are influenced by strip-mine reclamation techniques and by forest cover. Flow models to predict peak discharge, along with an updated flood frequency report, are to be prepared which are applicable to a wider range of land-use types than previously available.

Progress and significant results: Peak-stage cata and discharges for the 1986 water year were obtained for 30 crest-stage stations. Basin characteristics--predominantly percent strip-mine and percent forest--have been determined from U.S. Geological Survey 7.5-minute topographic maps for 296 stream-gaging stations. Forty-nine of these gaged basins have been disturbed by surface mining. The percentages of basin area disturbed by mining range from 0.1 to 82.9 percent. 
AUTOMATIC MEASUREMENT OF TEMPERATURE, SPECIFIC CONDUCTANCE;, DISSOLVED OXYGEN AND PH IN SELECTED STREAMS IN OHIO (OH 042 )

Period of Project:

Continuous (re-established

October 1985)

Project Leader:

Max S. Katzenbach

\section{Cooperator:}

Ohio Environmental Protection Agency

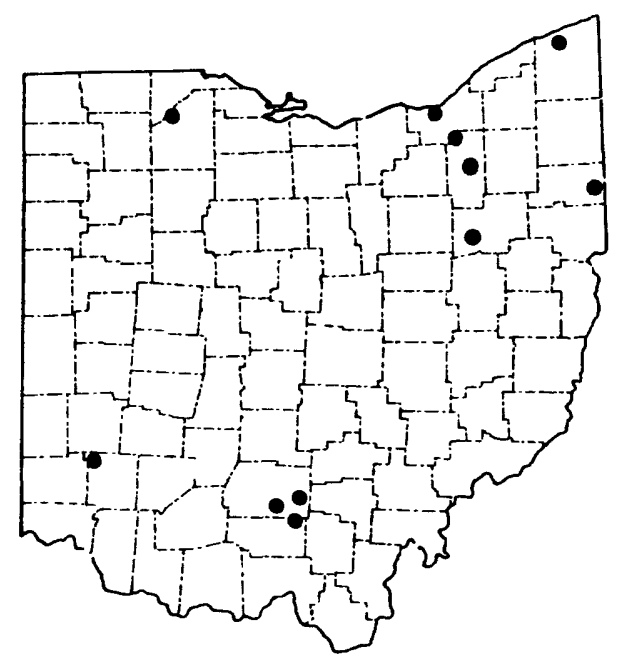

Purpose: (1) To continuously collect stream-temperature, dissolved-oxygen, specific-conductance and $\mathrm{pH}$ data, which will serve (either as direct or surrogate) indicators of water quality conditions in analyses conducted by the U.S. Geological Survey and state agencies to determine the impact and severity of man's influence on surface waters; and (2) provide relevant standardized data collected continously for comprehensive study by the U.S. Geological Survey and other agencies.

Progress and significant results: Data collection and processing continued at all 10 stations. This ten-station network, formerly considered part of the water-quality stations network, is now a separate project. 
Period of Project: July 1985 to December 1987

Project Leader: Jeffrey T. de Roche

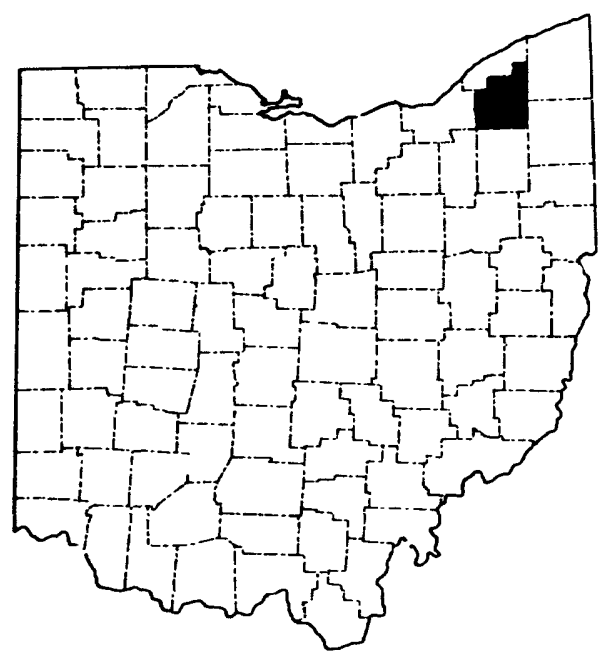

Purpose: Ground-water development for domestic and industrial water supplies is increasing in Geauga County. Many businesses and residences are being built in areas where the primary aquifer may not be able to produce sustained usable quantities of water. There are indications in the central and eastern parts of the county that several heavily utilized aquifers may be contaminated by brines generated by increased oil and gas production.

The objectives of the study are to: (1) Define the hydrogeology of the major aquifers; (2) determine if water levels and water quality have changed significantly since a study in 1978; (3) using computer simulation, predict what changes are likely to occur within the major aquifers; and (4) investigate possible ground-water contamination by brines from oil and gas production.

Progress and significant results: Additional geologic sections of the county have been prepared. Three rounds of routine waterlevel measurements were completed. Forty wells were sampled for ambient water quality. A three-dimensional ground-water flow model has been constructed. 
Period of Project:

February 1981 to December 1987

Project Leader:

James M. Sherwood

Cooperator:

Ohio Department of Transportation

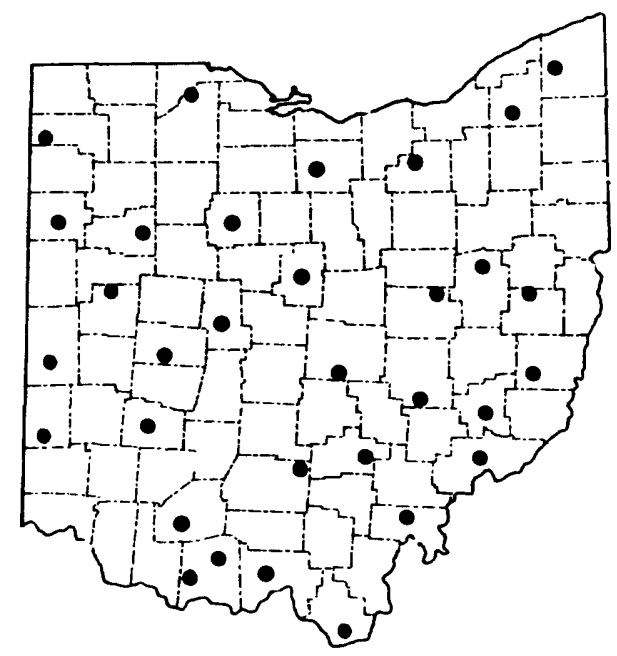

Purpose: To define the magnitude and frequency of flood volumes and to develop a method for deriving a design-flow hydrograph from small rural basins in Ohio. The information would be used by planners to design safe and economical hydraulic structures to convey floodflows. Complete hydrograph records for rural Ohio basins generally are lacking.

Progress and significant results: Data collection and processing continued at all 32 sites. Thirty-seven discharge measurements were made at 27 sites for theoretical rating verification. An average of 8.4 storm events per site were stored in computer files for water years 1982 and 1983 . Annual peak discharges for the 1984 water year were published in the annual water-resources data report. An interim report was prepared and approved. 
Period of Project:

March 1982 to September 1987

Project Leader:

Kevin J. Breen

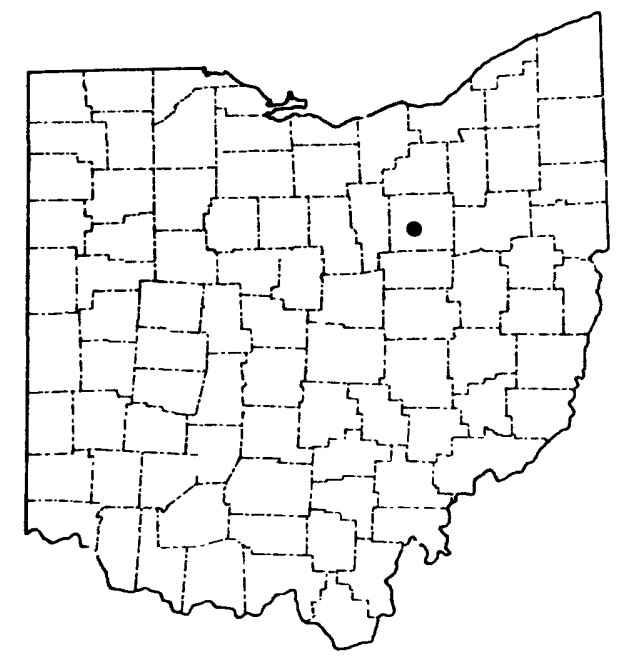

Purpose: To obtain a better understanding and definition of the flow characteristics of a glacial aquifer west of wooster, Ohio, as part of the Northeast Glacial Aquifers Regional Aquifer System Analysis study. Emphasis is placed on determining the contribution to pumping wells from stream infiltration and surrounding bedrock. Use will be made of stream and aquifer head relationships in combination with computer simulations of flow. Isotopic and inorganic-chemical characteristics of water also will be analyzed.

Progress and significant results: Thirteen observation wells have been installed in shallow (30 feet) and deep $(60+$ feet) glacial aquifers. Eleven well points driven into the channel of Killbuck Creek and Clear Creek have been added to this existing observation-well network. Stream-channel well points show groundwater heads consistently below water levels in the stream. Shallow and deep paired well points show lower heads in wells screened at deeper zones. Stream gain/loss studies show two tributary streams to Killbuck are losing 50 to 95 percent of flow during base-flow periods. Chemical characteristics of the ground water differ both areally and with respect to occurrence in shallow and deep water-yielding zones. Chemical-quality data indicate that water of the type observed in shale and sandstone bedrock is an important component in selected wells completed in the glacial aquifer. 


\section{SEDIMENTATION IN WHEELING CREEK BASIN, BELMONT COUNTY, OHIO \\ (OH068)}

Period of Project:

Continuous since July 1982

Project Leader:

G. F. Koltun

Cooperator:

Ohio Department of Natural Resources

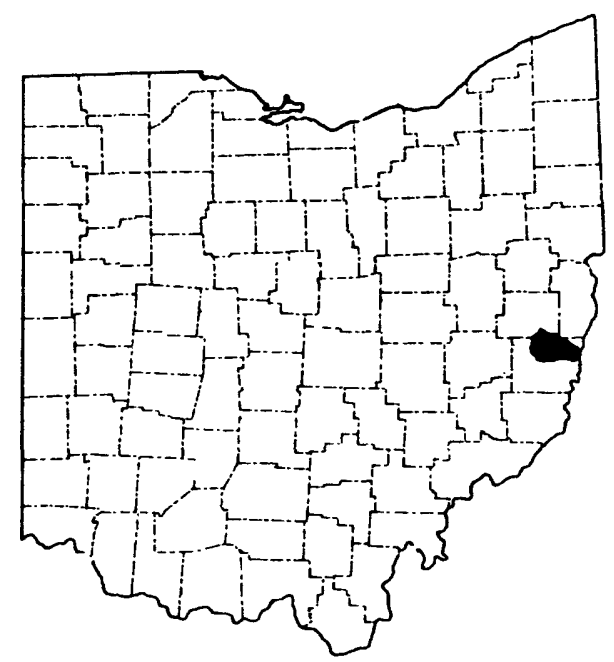

Purpose: To assess post-dredging trends in gross channel fill or scour in and around selected reaches of wheeling Creek.

Progress and significant results: Cross-section surveys continue on Wheeling Creek. Data collected to date show some localized evidence of scour and fill, however, no generalized gross trends are evident.. Daily discharge and suspended-sediment data continue to be collected at the gaging station (Wheeling Creek below Blaine, Ohio; station number 03111548). 
EFFECTS OF SURFACE-MINE RECLAMATION WITHIN

WEST BRANCH SHADE RIVER BASIN

(OH073)

Period of Project:

February 1983 through

December 1986

Project Leader:

Carolyn J. Oblinger Childress

Cooperator:

Ohio Department of Natural

Resources

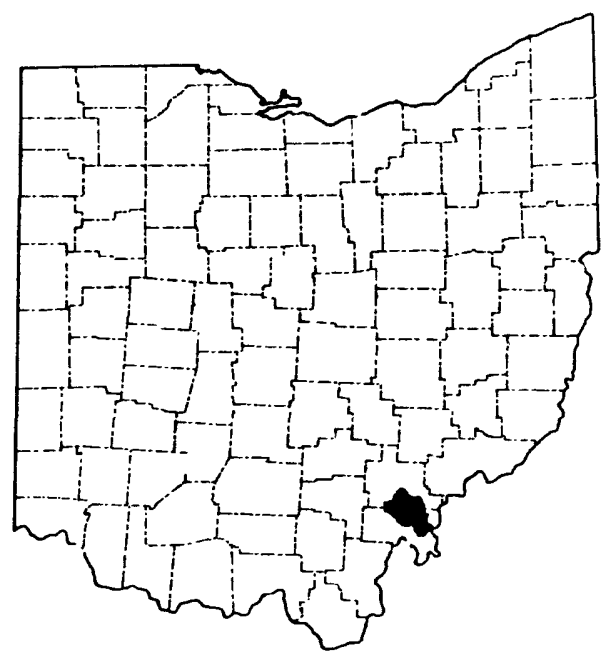

Purpose: Residents and local and State officials are concerned about sedimentation and flooding in the West Branch Shade River basin in Meigs and Athens Counties. The flooding may be due in part to a loss of conveyance of the channels caused by heavy sediment deposition from abandoned surface mines. The ohio Department of Natural Resources is reclaiming some of these mines, and data are needed to measure the effectiveness of reclamation.

The objectives of this study are to: (1) Measure changes in stream discharge and sediment concentrations at two points in the basin; (2) measure changes in water chemistry at three points in the basin; (3) measure sediment deposition and scour rates at nine typical stream cross-sections on west Branch Shade River and Kingsbury Creek; and (4) correlate discharge and sediment data from West Branch Shade River with data from part of the nearby East Branch Shade River basin, which is unaffected by mining.

Progress and significant results: Cross sections were surveyed, quarterly water-quality samples were collected, and daily sediment load and daily mean discharge were computed. From October 1984 through September 1986, suspended-sediment yield was 2 times higher in West Branch (0.51 tons/acre-foot of runoff) than East Branch (0.28 tons/acre-foot of runoff) Shade River. Preliminary analysis indicates that suspended-sediment yield from the headwaters of West Branch Shade River decreased significantly following reclamation (from 8.5 tons/acre-foot of runoff in the 1984 water year to 0.14 ton/acre-foot of runoff in the 1985 water year). In addition, acidity is higher, $\mathrm{pH}$ is lower, and concentrations of dissolved sulfate and metals are higher in the west Branch Shade River basin than in the East Branch Shade River basin. The first two preliminary reports have been published and a final report is in preparation. 
Period of Project:

September 1984 through March 1987

Project Leader:

Janet Hren

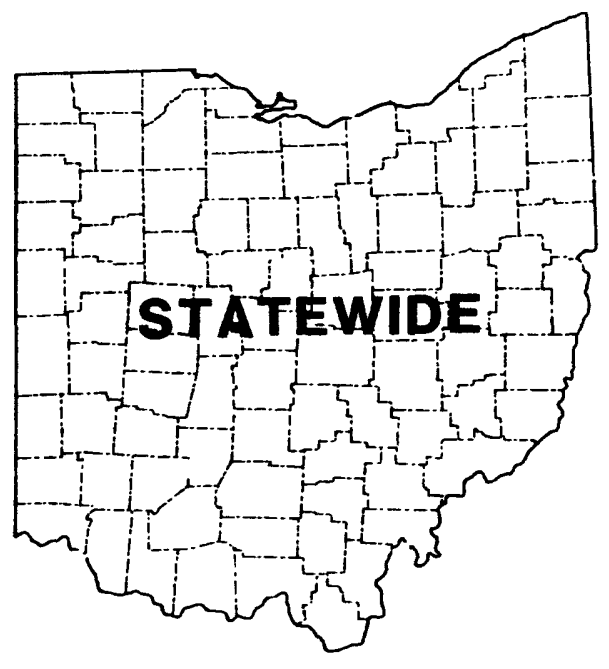

Purpose: The purpose of this study is to determine the extent to which existing water data, collected by different groups for various purposes and using different procedures, can be aggregated into a consistent data base for use in addressing selected water-quality questions of regional and national scope. Examples of such questions are:

1. What are (were) near-natural water-quality conditions?

2. What are existing water-quality conditions?

3. How has water quality changed, and how do the changes relate to human activity?

A three-phase approach was used. The objectives of these phases are:

Phase I. Identify and inventory water-quality data-collection programs, including costs, and identify those programs that meet a set of criteria for conducting broad-scope water-quality assessments.

Phase II. Evaluate the quality assurance of sampling techniques and laboratory methods used in collecting the data that meet the broad criteria of Phase I.

Phase III. Evaluate the applicability of these qualifying data for addressing selected water-quality questions of regional and national scope.

Progress and significant results: Phase I report completed and published as U.S. Geological Survey Open File Report 85-574, and also has been approved for publication as Water-Supply Paper 2295-A. The Phase II and Phase III reports are in preparation. 
Period of Project:

September 1984 through

September 1987

Project Leader:

Alban W. Coen, III

Cooperator:

City of Bryan, Ohio

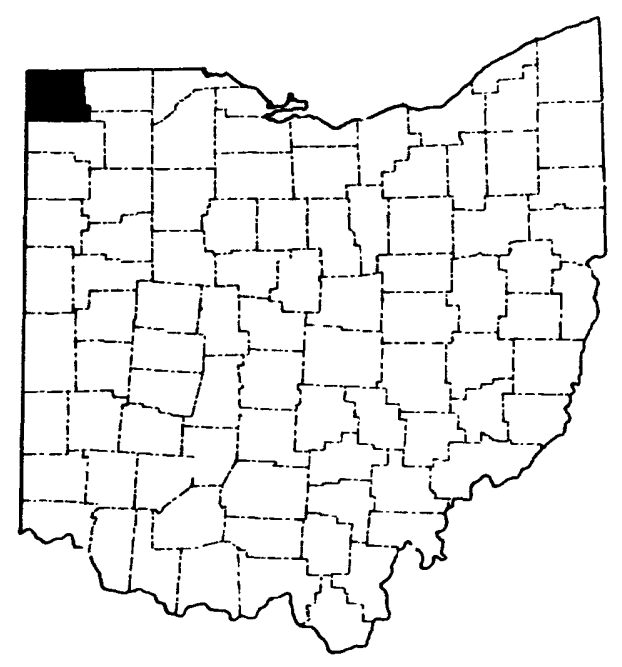

Purpose: Water for domestic, municipal, and industrial uses in williams county is totally derived from ground water. A better understanding of the hydrogeologic setting is needed to protect the resource and to manage potential problems. For example, municipal ground-water pumpage has significantly lowered the water table near Bryan.

The objectives of this project are to define the availability and quality of ground water in the shallow glacial aquifers in hilliams County, Ohio, by: (1) Literature and data search, (2) collecting ground-water level and quality data, (3) constructing and calibrating a quasi three-dimensio al ground-water flow model, (4) using surface geophysics and well iogs to define the hydrogeologic system, and (5) measuring stream gains and losses.

Progress and significant results: Water levels in 80 wells have been measured quarterly for 18 months. Most areas in the county showed 2 or 3 feet of annual fluctuation in water level. Regional ground-water flow is to the southeast, with local flow towards streams.

Water samples from 48 wells and 4 streams, including domestic, commercial, and municipal water supplies, were collected and analyzed for common dissolved constituents in April, August, and November, 1985. Preliminary results show generally good water quality. 
Period of Project:

October 1984 through June 1987

Project Leader:

Karen S. Wilson

Cooperator:

Ohio Department of Natural Resources

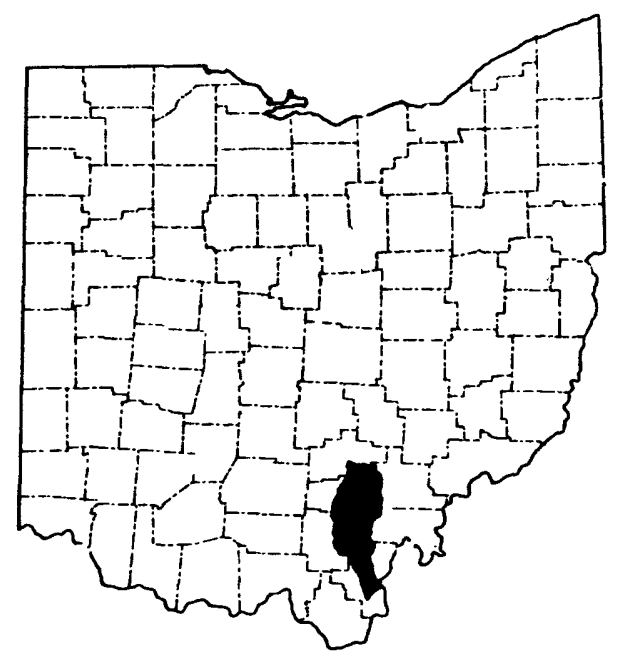

Purpose: The Ohio Department of Natural Resources, Division of Reclamation, is planning to reclaim many of the abandoned surface mines that are producing acid mine drainage in the Raccoon Creek basin. Water-quality conditions before reclamation needs to be defined.

The objectives of this study are to: (1) Document water quality throughout the basin, (2) determine macroinvertebrate abundance and diversity at selected points representing the entire basin, and (3) measure rates of deposition and scour in the basin as a whole.

Progress and significant results: During water-year 1986, the project was suspended for a short period due to funding difficulties. Because significant reclamation was not scheduled to begin in the basin until after data collection was completed, several changes in purpose and approach were made when the project was reinstated. This project is now scheduled to be suspended in June 1987 and restarted in July 1988. All five gaging stations were discontinued and removed. Water-quality data collection was completed quarterly at 17 sites, and macroinvertebrate data were collected twice at the same 17 sites. 
QUALITY OF SURFACE WATER AND GROUND WATER IN ACTIVE COAL MINING AREAS OF OHIO

(OH084)

Period of Project:

July 1985 to October 1992

Project Leader:

Allison Jones

Cooperator:

Ohio Department of Natural

Resources-Division of

Reclamation

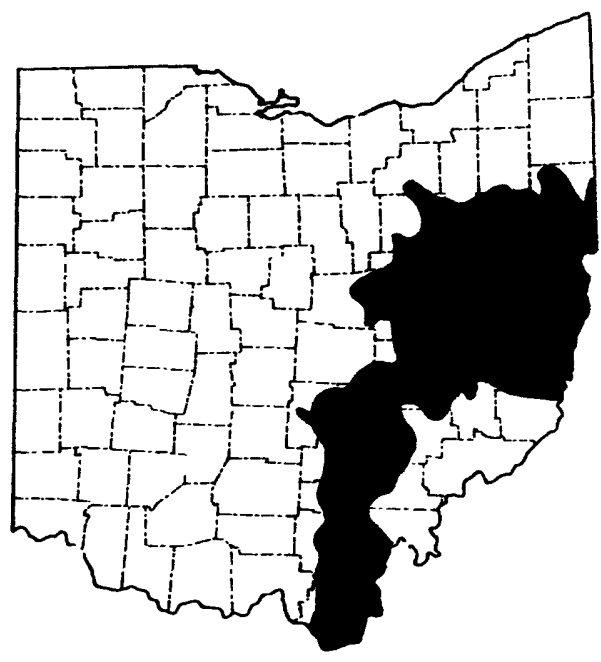

Purpose: The Ohio Department of Natural Resources needs baseline ground-water and surface-water quality data in the active coal mining areas of Ohio. This dat? will be used for surface mining permit application and compliance aj well as to assess the impact of present and future mining and reclamation. Twenty basins in southeastern ohio will be investigated and monitored during a 7-year period.

Progress and significant results: The following basins have been intensely investigated:

Stillwater Creek

Symmes/Ice/Indian Guyan Creeks

Moxahala Creek

Little Beaver Creek

McMahon/Captina/Sunfish Creeks.

A basin which has been intensely investigated includes the collection of ten additional surface-water samples, four ground-water samples, and the definition of the approximate location and extent of a productive shallow aquifer in the basin.

A network of 40 long-term surface-water sites (sampled twice yearly) is also distributed throughout the study area. 
NORTHWESTERN OHIO GROUND WATEh

(OH085)

Period of Project:

October 1985 through July 1988

Project Leader:

Kevin J. Breen

Cooperators:

Wood County

Lucas County

Sandusky County

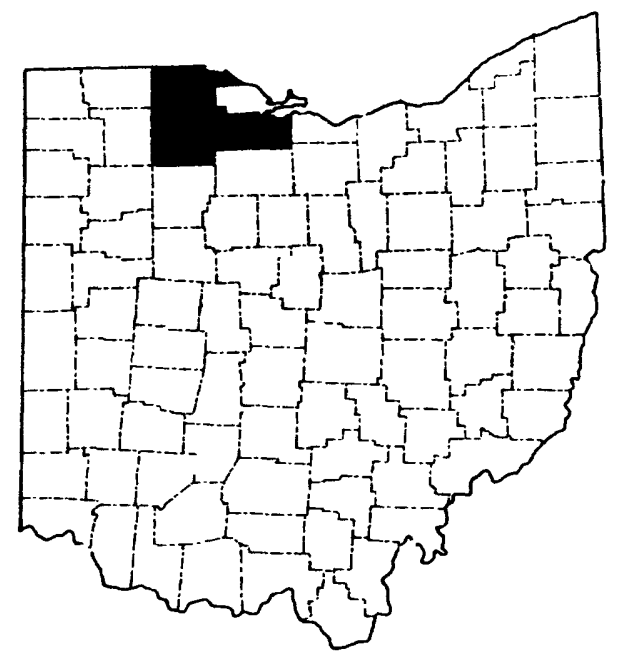

Purpose: The County planners and health officials of Lucas, Sandusky, and wood Counties, in northwestern Ohio, are faced with increasing concerns relating to contamination and use of their ground-water resources. A regional ground-water network needs to be established to inventory in detail the location of wells and to provide geohydrologic data, aquifer-head data, and ground-waterquality baseline information.

The objective of this study is to assess the ground-water resources of Lucas, Wood, and Sandusky counties, and to (I) describe the hydrogeologic framework of the regional Silurian- and Devonianage bedrock carbonate aquifer; (2) describe the hydrogeologic framework of selected Pleistocene-age surficial aquifers; (3) define the direction of ground-water movement; (4) develop a regional ground-water-quality baseline, using historic data and proposed data collection; and (5) compare the quality of water from selected springs and quarry seeps with ground water from wells near these sites.

Progress and significant results: A network of 350 wells has been established to monitor water levels in the Silurian-Devonian carbonate (dolomite) aquifer. Seventeen wells have been located or installed as part of the water-level and water-quality network in the sandhills region of Lucas County. 
GROUND-WATER MOVEMENT AND QUALITY IN NORTHEAST UNION COUNTY, OHIO UNION COUNTY

(OH086)

Period of Project:

July 1985 through December 1986

Project Leader:

Karen S. Wilson

Cooperators: City of Richwood

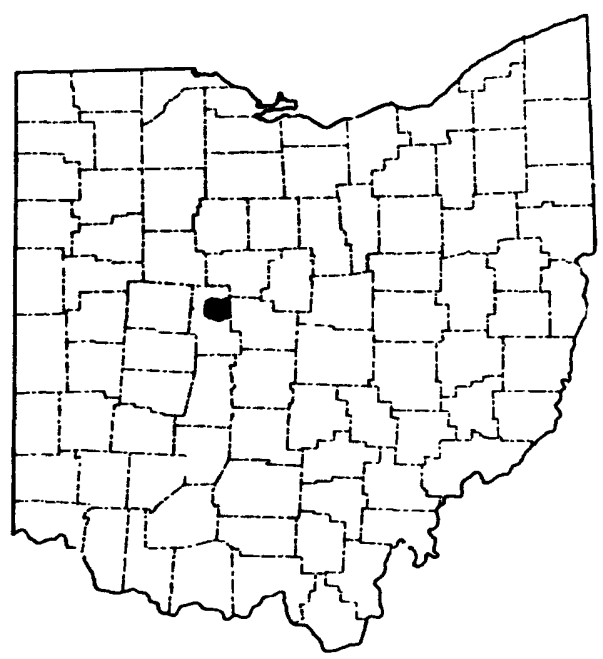

Purpose: The people of northeastern Union County and the City of Richwood are concerned about the quality of their water supply, which has had elevated ammonia and nitrite concentrations for several years. A description and definition of the groundwater hydrology and water quality would provide backgrouond information needed to evaluate the susceptibility of present and future water supplies to ground-water contamination.

The objective of this study is to describe the ground-water hydrology and water quality of northeastern Union County by determining (1) the flow directions and seasonal ground-water fluctuations, and (2) time and areal variations in the quality of the ground water.

Progress and significant results: Quarterly water-level measurements were completed, and groundwater was determined to be in an easterly direction. Fourteen wells and Richwood Lake were sampled twice for chemical quality. No presence of organic chemicals or pesticides were found. Several well elevations were surveyed and a seepage measurement on Fulton Creek was conducted. All data-collection tasks were completed. 
Period of Project:

September 1985 through

September 1989

Project Leader:

Rick L. Jones

\section{Cooperators:}

U.S. Office of Surface Mining

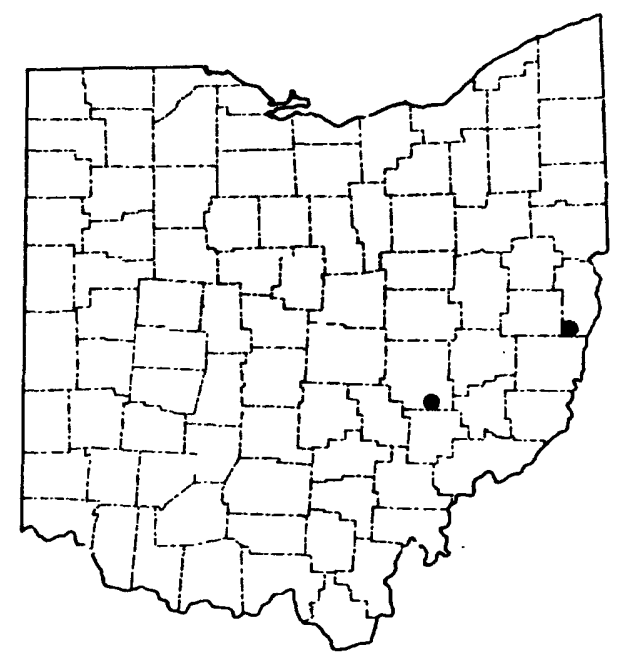

Problem: Long term impacts of surface coal mining on groundwater quality and quantity are poorly defined. Resaturation rates, recharge capacity, conductivity, storage, quality, and movement are a few of the hydrologic conditions not completely understood.

The objectives of this study are to (1) describe occurrence of ground water in and beneath the overburden soils of the reclaimed area, (2) describe rates of resaturation, and (3) evaluate chemical changes in the water quality.

Watersheds will be visited bimonthly for water-level measurements. Water quality samples will be taken from four wells semiannually and from stream and seeps annually. Variations of chemical composition will be identified by the use of Stiff and Piper diagrams.

Progress and significant results: Water levels and waterquality samples have been completed for 1986. No significant results have been noted to date. 
TECHNIQUES FOR OPERATING IN SITU WATER-QUALITY MONITOR STATIONS (OH089)

Period of Project:

October 1985 through March 1987

Project Leader:

Max S. Katzenbach

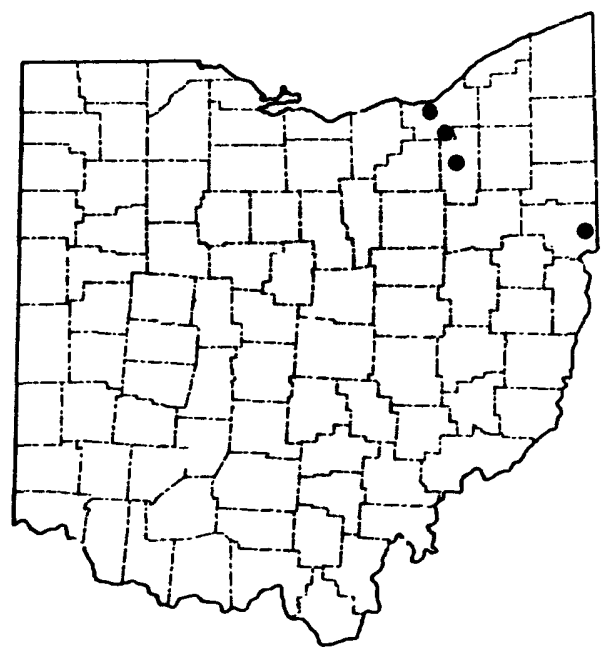

Problem: There are questions to be answered regarding the use of a "packaged-sensor" type of in situ water-quality monitor as opposed to the U.S. Geological Survey's minimonitor: (1) How reliable is each system under field conditions; (2) what is the cost of operation and maintenance of each system; and (3) how do the data from each system compare with the standard flow-through monitors.

The objective of this study is to evaluate the technicalities and economics of operating these two monitor systems. In situ monitors with packaged sensors and minimonitors have been installed at four flow-through monitor sites to analyze (I) the possible reduction in costly field time required to service monitor stations and (2) increased reliability of monitor stations and their records.

Progress and significant results: Data were collected for one year and stored in computer files. Sites were visited every 2 weeks and data verified by making field measurements. Preliminary indications are that packaged-sensor systems would be cheaper to operate and just as reliable as the minimonitors. 


\section{SURFACE-WATER STATIONS FOR WHICH RECORDS ARE PUBLISHED}

The tables in this section list hydrologic data stations for which daily records have been published by the U.S. Geological Survey in 1986. Surface-water stations are numbered and Iisted in downstream order along the main stem. A station on a tributary entering between two main-stem stations is listed between them. A similar order is followed in listing stations on first rank, second rank, and other ranks of tributaries. This downstream order numbering system is a permanent system of numerical designations adopted by the survey in 1950.

Surface-water stations for which daily data are collected are classified as: Discharge, stage only, sediment, continuousrecord water quality, and reservoir or lake contents and (or) elevation. Daily discharge and stage-only stations are sites instrumented to provide a continuous stage record. For daily discharge stations, calculations of mean daily discharge, peak flows during floods, and total monthly and yearly runoff are made by applying stage data to a stage-discharge rating curve derived from actual discharge measurements.

Pool-elevation data collected at reservoir or lake stations are used to determine periodic changes in the amount of water held in storage. Continuous-record water-quality stations are sites equipped to record one or more physical or chemical characteristics. The record is used to determine maximum and minimum daily values. For daily sediment stations, samples collected daily are analyzed for their suspended-sediment concentrations to develop a curve from which daily mean concentrations are determined. Suspended-sediment discharges are computed by multiplying water discharge times concentration times a conversion factor.

In addition to the daily stations listed, data are collected at many sites where daily stations are not feasible. At these "partial-record stations," data are collected at regular intervals ranging from once to several times annually. Types of data collected include peak discharge, low-flow discharge, chemical quality, sediment, and biologic. Information about locations of partial-record stations and types of data collected is available upon request. 
[Letter after station name designates type of data: (B) biological, (C) chemical, (D) discharge, (E) contents and (or) elevation, (M) microbiological, (NASQAN) National stream-quality accounting network, (R) radiochemical, (S) sediment, and (T) temperaturel

Station number

03086500

03090500

03091500

03092000

03092090

03092460

03093000

03094000

03095500

03099500

03099510

03102950

03109500

03110000

03111500

03111548

03114000

03117000

03117100

03117500

03118000

03118500
Station

Type of data
Ohio River:

BEAVER RIVER BASIN

Mahoning $R$ (head of Beaver $R$ ) at Alliance

Mahoning $\mathrm{R}$ bl Berlin Dam, nr Berlin Center

Mahoning $R$ at Pricetown

Kale C nr Pricetown

$W$ B Mahoning $R$ nr Ravenna

$W$ B Mahoning $R$ bl M. J. Kirwan Dam, at Wayland

Eagle $C$ at Phalanx Station

Mahoning $\mathrm{R}$ at Leavittsburg Mosquito Creek:

Mosquito C bl Mosquito C Dam, nr Cortland D

Mahoning $R$ at Lowellville

Mahoning $\mathrm{R}$ at $\mathrm{Oh}-\mathrm{Pa}$ State line bl Lowellville Shenago River: Pymatuning $\mathrm{C}$ at $\mathrm{K}$ insman

LITTLE BEAVER CREEK BASIN

North Fork I Beaver Creek:

L Beaver C nr East Liverpool

YELLOW CREEK BASIN

Yellow C nr Hammondsville

SHORT CREER BASIN

Short Creek:

Short C nr Dillonvale

WHEELING CREER BASIN

Wheeling Creek:

Wheeling $\mathrm{C}$ bl Blaine

CAPTINA CREEK BASIN

Captina $\mathrm{C}$ at Armstrong Mills

MUSKINGUM RIVER BASIN

Tuscarawas $R$ (head of Muskingum $R$ ):

Tuscarawas $R$ at Massillon

Tuscarawas $R$ at Navarre

Sandy $C$ at Waynesburg

$M$ B Nimishillen C (head of Nimishillen Creek) at Canton

Nimishillen $C$ at North Industry
D

D

DS

D

D

CT

D

D

D

D

D

D

D

CT

D

D

D

D

D

D 
SURFACE-WATER STATIONS--Continued

Station

number

03120500

03122500

03124000

03124500

03126000

03127000

03127500

03128500

03129000

03130000

03131500

03133500

03135000

03136500

03138500

03139000

03140000

03140500

03141500

03142000

03143500

03144000

03145000

03146500

03147500

03150000

03142290

03157000

03157500

03159510
Station

Type of

data

McGuire Creek:

McGuire C bl Leesville Dam, nr Leesville D

Tuscarawas $\mathrm{R}$ bl Dover Dam, $\mathrm{nr}$ Dover

Sugar Creek bl Beach City Dam, nr Beach City D

Sugar Creek at Strasburg D

Stillwater Creek:

Stillwater C at Piedmont D

Stillwater $C$ at Tippecanoe D

Stillwater C at Uhrichsville D

Clear Fork (head of L Stillwater Creek):

L Stillwater C bl Tappan Dam, at Tappan D

Tuscarawas $R$ at Newcomerstown D

Black $F$ (head of Walhonding River) bl

Charles Mill Dam, nr Mifflin D

Black $F$ at Loudonville D

Clear F bl Pleasant Hill Dam $\mathrm{nr}$ Perrysville D

Mohican $R$ (continuation of Black Fork):

Lake Fork:

L F bl Mohicanville Dam, nr Mohicanville D

Kokosing $\mathrm{R} \mathrm{nr}$ Mount Vernon D

Walhonding $R$ (continuation of Mohican $R$ ) bl

Mohawk Dam, at Nellie D

Killbuck C at Killbuck D

Mill C nr Coshocton D

Muskingum $R$ (continuation of Tuscarawas $R$ ) $n r$ Coshocton

Wills Creek:

Seneca Fork:

Seneca F bl Senecaville Dam, nr Senecaville D

Wills $C$ at Cambridge D

Wills C bl Wills C Dam, at Wills Creek D

Wakatomika C nr Frazeysburg D

Licking River

$S$ F Licking $R$ (head of Licking River) nr Hebron

Licking $\mathrm{R} \mathrm{nr}$ Newark

Licking $R$ bl Dillon Dam, $\mathrm{nr}$ Dillon Falls $\mathrm{D}$

Muskingum $R$ at McConnelsville (NASQAN)

Muskingum River basin, Salt Fork Re E

HOCKING RIVER BASIN

Hocking River:

Clear C nr Rockbridge D

Hocking River at Enterprise D

Focking River bl Athens (NASQAN) DCBS 
SURFACE-WATER STATIONS--Continued

Station number

03159540

03219500

03219590

03220000

03221000

03223000

03225500

03227500

03228500

03228805

03229000

03229500

03230500

03230900

03231000

03231500

03232470

03232500

03234000

03234300

03234500

03237280

03237500

03238500

03240000

03241500

03245500

03247050

03247500

03255500

03259000
Station

Type of

data

SHADE RIVER BASIN

Shade $\mathrm{R} n \mathrm{r}$ Chester

RACCOON CREER BASIN

Raccoon Creek:

SCIOTO RIVER BASIN

Scioto R nr Prospect

Bokes C nr Warrensburg

Mill C nr Bellepoint

Scioto $\mathrm{R}$ bl O'Shaughnessy Dam $\mathrm{nr}$ Dublin

Olentangy River:

Olentangy $R$ at Claridon

Olentangy $R \mathrm{nr}$ Delaware

Scioto $R$ at Columbus

Big Walnut $\mathrm{C}$ at Central College

Alum $C$ at Africa

Alum $C$ at Columbus

Big Walnut $\mathrm{C}$ at Rees

Big Darby $C$ at Darbyville

Deer C nr Pancoastburg

Deer $C$ at Williamsport

Scioto $R$ at Chillicothe

Paint Creek:

Paint C bl Paint C Dam nr Bainbridge Rocky Fork:

Rocky F nr Barretts Mills

Paint C nr Bourneville

Paint $C$ at Chillicothe

Scioto $R$ at Higby (NASQAN)

Reservoirs in Scioto $R$ basin

UPPER TWIN CREER BASIN

Upper Twin C at McGaw (HBM)

OHIO BRUSH CREER BASIN

Ohio Brush C nr West Union

D

D

D

D

D

D

D

D

D

D

D

D

D

D

D

DCT

D

D

D

DCT

DCBMTS

E

DCMSRT

D

D

Whiteoak C nr Georgetown

LITTLE MIAMI RIVER BASIN

L Miami R nr oldtown

Massies $C$ at Wilberforce

L Miami $R$ at Milford (NASQAN)

E F L Miami R nr Batavia

E F L Miami $R$ at Perintown

MIAMI CREER BASIN

Mill $C$ at Reading

Mill $\mathrm{C}$ at Carthage
D

D

DCBMTS

D

D

D

$\mathrm{D}$ 
SURFACE-WATER STATIONS--Continued

Station

number

Station

Type of data

03260700

03261500

03261950

03262000

03262700

03263000

03264000

03265000

03266000

03267000

03267900

03269500

03270000

03270500

03270800

03271500

03271510

03271800

03272000

03272700

03274000

03274600

04177000

04185000

04185440

04186500

04189000

04191500

04192500

04193490

04193500

04194107

04195500

04196800

04197020

04197100

GREAT MIAMI RIVER BASIN

G Miami River:

Bokengehalas C nr De Graff D

G Miami R at Sidney D

Loramie C nr Newport D

Loramie C at Lockington D

G Miami R at Troy D

G Miami R at Taylorsville D

Stillwater River:

Greenville C nr Bradford D

Stillwater $\mathrm{R}$ at Pleasant $\mathrm{Hill}$ D

Stillwater $R$ at Englewood D

Mad R nr Urbana D

Mad R (at St. Paris Pike) at Eagle City D

Mad R nr Springfield D

Mad $R$ nr Dayton D

G Miami R at Dayton D

Wolf C at Trotwood D

G Miami R at Miamisburg D

G Miami $R$ nr Linden Ave at Miamisburg CT

Twin C nr Ingomar D

Twin C nr Germantown D

Sevenmile Creek:

Sevenmile $\mathrm{C}$ at Camden D

G Miami at Hamilton D

G Miami $R$ at New Baltimore (NASQAN) CBMTS

ST LAWRENCE RIVER BASIN

(STREAMS TRIBUTARY TO LAKE ERIE)

Ottawa $\mathrm{R}$ at Toledo University D

Tiffin $\mathrm{R}$ at Stryker D

Lost C nr Farmer D

Auglaize $\mathrm{R}$ nr Ft Jennings D

Blanchard $\mathrm{R}$ nr Findlay D

Auglaize $\mathrm{R}$ n Defiance D

Maumee $R$ near Defiance D

Maumee $\mathrm{R} n \mathrm{n}$ Waterville $\mathrm{CT}$

Maumee $\mathrm{R}$ at Waterville (NASQAN) DCBMT

Lake Erie at Reno Beach E

Portage $\mathrm{R}$ at Woodville D

Tymochtee $\mathrm{C}$ at Crawford D

Honey C nr New Washington D

Honey $\mathrm{C}$ at Melmore D 
SURFACE-WATER STATIONS--Continued

Station number

04197170

04198000

04199160

04199165

04199170

04200500

04201500

04202000

04206000

04207200

04208000

04208502

04208506

04212100

04212200

04212680

04213000

Station

Type of data

D

Rock $C$ at Tiffin

Sandusky R near Fremont (NASQAN)

Old Woman's C ab U.S. $6 \mathrm{nr}$ Huron

Old Woman's C at U.S. $6 \mathrm{nr}$ Huron

Lake Erie at Huron

Black $R$ at Elyria

Rocky $R$ nr Berea

Cuyahoga $R$ at Hiram Rapids

Cuyahoga $R$ at old Portage

Tinkers $\mathrm{C}$ at Bedford

Cuyahoga $R$ at Independence (NASQAN)

Big C at Cleveland

Cuyahoga $R$ at $W$ 3rd st bridge in cleveland

Grand $\mathrm{R} \mathrm{nr}$ Painesville

Grand $R$ at Painesville (NASQAN)

Fields Brook at Ashtabula

Conneaut $\mathrm{C}$ at Conneaut

STANDARD ABBREVIATIONS USED IN STATION NAMES

$\begin{array}{llllll}\text { ab } & \text { above } & \text { e } & \text { east } & \text { nr } & \text { near } \\ \text { b } & \text { branch } & \text { f } & \text { fork } & \text { r } & \text { river } \\ \text { bk } & \text { brook } & \text { g } & \text { great } & \text { re } & \text { reservoir } \\ \text { bl } & \text { below } & \text { l } & \text { little } & \text { rn } & \text { run } \\ \text { c } & \text { creek } & \text { lk lake } & \text { s } & \text { south } \\ \text { ca } & \text { canal } & \text { m middle } & \text { tr } & \text { tributary } \\ \text { d } & \text { ditch } & \text { n north } & \text { w } & \text { west }\end{array}$

GROUND-WATER STATIONS FOR WHICH RECORDS ARE PUBLISHED

The following table lists the ground-water stations in Ohio for which the U.S. Geological Survey is publishing data in 1986. The first six digits of the well numbers denote degrees, minutes, and seconds of latitude, and the next seven digits denote degrees, minutes, and seconds of longitude. The last two digits are used, if needed, for sequential numbering within a 1-second grid.

In addition to the sites listed, data on water levels, yield, and chemical quality of ground water have been collected at many other locations in ohio. Information about these miscellaneous measurements is available upon request. 
GROUND-WATER STATIONS FOR WHICH RECORDS ARE PUBLISHED

[Letter after station location designates type of data: c chemical; 1, water level.]

We11 number

405303082170700

405425082173000

392004082071600

392009082072200

403233083574500

400118081082200

391805084261800

393202084241500

391904084371800

392017084345200

392021084340300

392048084311400

392445084333000

392515084322000

392733084293000

392939084231700

393103084240900

403709081052800

400638083453900

395639084012200

395840083495200

Local number

Location

ASHLAND COUNTY

AS-2

AS-3

AT-2A

$\mathrm{AT}-5$

$\mathrm{AU}-3$

B-3

$\mathrm{BU}-9$

BU-15

$\mathrm{BU}-12$

$\mathrm{BU}-7$

$\mathrm{BU}-56$

$\mathrm{BU}-8$

$\mathrm{BU}-36$

$\mathrm{BU}-5$

$\mathrm{BU}-16$

$\mathrm{BU}-3$

$\mathrm{BU}-2$

C-I

$\mathrm{CH}-3$

CL-9

$\mathrm{CL}-7$
Ashland (1)

Jerome Fork (I)

ATHENS COUNTY

Athens (1)

Athens (I)

\section{AUGLAIZE COUNTY}

Southwest of

New Hampshire (1)

BELMONT COUNTY

Mount Olivett (1)

BUTLER COUNTY

Northwest of Sharonville (I)

Middletown (1)

East of Ross (1)

Fairfield (1)

Fairfield (1)

East of Hamilton (1)

Hamilton (c)

North of Hamilton (1)

Southwest of Trenton (1)

Middletown (1)

Middletown (1)

CARROLL COUNTY

North of Carroliton (I)

CHAMPAIGN COUNTY

Urbana (1)

CLARK COUNTY

New Carlisle (1)

Northwest of Springfield (1) 
GROUND-WATER STATIONS--Continued

Well number

404838082563100

400514084345700

402126083040400

394257082362900

394544082271000

395053082361900

393153083322000

394956083002700

395118083573300

395157083003500

400101083021800

383638082103300

412518081221500

394411083561300

394425083551100
Local nuniner

Location

COSHOCTON COUNTY

North of Conesville (I)

CRAWFORD COUNTY

CR-1

Bucyrus (I)

DARKE COUNTY

D-2

East of Greenville

(1)

DELAWARE COUNTY

DL-3

Delaware (1)

FAIRFIELD COUNTY

F-6

F-1

F-5

Lancaster (1)

West Rushville (I)

Baltimore (1)

FAYETTE COUNTY

FA-1

West of Washington

Court House (1)

FRANKLIN COUNTY

F R -18

FR-3

FR-109

FR-10

G-2

East of Crown City

GEAUGA COUNTY

$\mathrm{GE}-3 \mathrm{~A}$

Southeast of Chagrin Falls

(1)

GREENE COUNTY

GR-I

GR-10
North of Xenia (1)

North of Xenia (1) 
GROUND-WATER STATIONS--Continued

Wel1 number

Local number

Location

HAMILTON COUNTY

391039084291500

391101084172100

391201084281600

391214084470100

391324084272500

391341084275300

391442084262900

391608084254400

391733084392400

391748084393800

391817084393300

404218083503700

404648083412600

412123083574000

393200082235300

402344082300700

413704083362200

395301083272200

395357083304400

395740083255700

410042080453800

403413083170500

403443083230400

403601083110400
$\mathrm{H}-11$

$\mathrm{H}-3$

$\mathrm{H}-10$

$\mathrm{H}-1$

$\mathrm{H}-9$

$\mathrm{H}-8$

$\mathrm{H}-7$

$\mathrm{H}-6$

$\mathrm{H}-2$

$\mathrm{H}-19$

$\mathrm{H}-4$

HN-1

$\mathrm{HN}-2 \mathrm{~A}$

HY -2

HK-1

$\mathrm{K}-1$

LU-1

M-2

$M-4$

M-3

MA-1

$\mathrm{MN}-4$

$\mathrm{MN}-1$

$\mathrm{MN}-2$
Cincinnati (I)

Southeast of Miamiville (1)

Cincinnati ( 1 )

Southeast of Harrison (1)

Cincinnati (I)

Wyoming (I)

Evendale (I)

Glendale (1)

South of Ross (1)

Southwest of Venice (c)

Southwest of Ross (I)

HARDIN COUNTY

Alger (1)

Southeast of Dola (1)

HEN RY COUNTY

Southwest of McClure (1)

HOCKING COUNTY

Logan (I)

KNOX COUNTY

Mt. Vernon (1)

LUCAS COUNTY

Toledo (1)

MADISON COUNTY

London (1)

Northwest of London (1)

North of London (1)

MAHONING COUNTY

Canfield (I)

MARION COUNTY

Southeast of New Bloomington (1) LaRue (1)

West of Marion (1) 
GROUND-WATER STATIONS--Continued

Well number

410120081431800

410142082005900

402833084375200

395848084085500

400208084112900

393757084173600

394012084151700

394025084162800

394425084113200

394533084113800

395804081593200

393327082571600

393402082572500

393638082572300

393438083072200

390359083015100

411401081025000

410540081213600

410920081192000

394438084335900
Local number

Location

MEDINA COUNTY

$$
\begin{aligned}
& M D-3 \\
& M D-1
\end{aligned}
$$

Wadsworth (1)

Lodi (1)

MERCER COUNTY

MR-2

Coldwater (1)

MIAMI COUNTY

MI -3

MI -44

Northeast of Tipp City

Troy (c)

MONTGOMERY COUNTY

MT-928

MT-55

MT- 49

MT-3

MT-6

Miamisburg (c)

West Carrollton (I)

West Carrollton (1)

Dayton (1c)

Dayton (1)

MUSKINGUM COUNTY

MU-1A

Zanesville (1)

PICKAWAY COUNTY

PK -7

PK -4

PK -6

PK-8

South of Circleville (1)

South of Circleville (1)

Northwest of Circleville (1)

Williamsport (1)

PIRE COUNTY

PI-2

West of Piketon (1)

PORTAGE COUNTY

PO- 1

$\mathrm{PO}-7$

PO- 6

Windham (1)

Brimfield (1)

East of Kent (1)

PREBLE COUNTY

PR-2
(1) 
GROUND-WATER STATIONS--Continued

We11 number

Local number

Location

PUTNAM COUNTY

405505084032900

PU-1

Columbus Grove (I)

RICHLAND COUNTY

404625082305100

$\mathrm{R}-4$

Mansfield (1)

405753082360800

391341083172200

391913082580500

412703083213600

410802083093900

401712084103500

404939081203800

405051081244200

405211081253500

410141081315200

410330081282000

410846081271600

411604080505600

403207081293800

403557081313600

403653081321800

403823081324200
$\mathrm{R}-3$

$\mathrm{RO}-7$

$\mathrm{RO}-8$

S-3

S-2

Shiloh (1)

ROSS COUNTY

West of Bainbridge (1)

Chillicothe (1)

SANDUSKY COUNTY

Fremont (I)

Woodville (1)

SENECA COUNTY

SE-2

Tiffin (1)

SHELBY COUNTY

SH-4

Sidney (1)

ST-5A

ST-28

$\mathrm{ST}-27$

STARK COUNTY

Canton (1)

Northwest of Canton (1)

North Canton (1)

SUMMIT COUNTY

$S U-4 A$

SU-6

SU-7

Akron (I)

Akron (1)

Cuyahoga Falls (1)

TRUMBULL COUNTY

$\mathrm{T}-3$

Near Warren (1)

TUSCARAWAS COUNTY

TU-3

TU-4

Dover (1)

St rasburg (I)

$\mathrm{TU}-1$

North of strasburg

(1) 
GROUND-WATE R STATIONS--Continued

401826083255200

405215084335400

391452082282900

392712084191700

392553081281600

404655081553200

404802081583100

405745081510200

405805081462300

412821084313600

412930084320900

413108084415300

405009083172600
$\mathrm{U}-4$

VW-1

$\mathrm{V}-\mathrm{I}$

W-5

WA-2

WN -3

WN-2A

$\mathrm{WN}-7$

WN-6

WM-I

WM-3

WM-12

WY-1
UNION COUNTY

Southeast of Raymond (1)

VAN WERT COUNTY

Van Wert (1)

VINTON COUNTY

McArthur (1)

WARREN COUNTY

East of Monroe (1)

WASHINGTON COUNTY

Marietta (1)

WAYNE COUNTY

Near Wooster (I)

Near Wooster (I)

Near Sterling (1)

Rittman (1)

WILLIAMS COUNTY

Near Bryan (I)

Bryan (1)

East of Blakeslee (I)

WYANDOT COUNTY

Upper Sandusky (I) 
Selected references on water resources in Ohio are listed below; many of them are available for inspection at the Ohio District office and at large public and university libraries. The publications are grouped as follows: (1) U.S. Geological Survey publications; (2) reports prepared by the Geological survey in cooperation with specific agencies and which can be obtained from the cooperating agencies; and (3) other publications, such as contributions to technical journals.

\section{Professional Papers}

450-B Temperature-depth relations in wells as indicators of semiconfining beds in valley-train aquifers, by $S$. E. Norris and A. M. Spieker. 1962.

450-E Permeability of glacial till, by s. E. Norris. 1963.

475-D Anomalous streamflow-ground-water regimen in the Mad River basin, near springfield, Ohio, by W. P. Cross and A. J. Feulner. 1963.

Geology and ground-water resources of Portage County, Ohio, by J. D. Winslow and G. W. White. 1966.

525-D Relation of permeability to particle size in a glacialoutwash aquifer at Piketon, Ohio, by S. E. Norris and and R. E. Fidler. 1965.

550-C Water-quality variations in the Cuyahoga River at Cleveland, Ohio, by M. E. Schroeder and C. R. Collier. 1966.

550-D Effect of sampling and testing methods on computed hydraulic properties of glacial outwash at Piketon, Ohio, by S. E. Norris and R. E. Fidler. 1966.

605-A Ground-water hydrology and geology of the lower Great Miami River valley, Ohio, by A. M. Spieker. 1968.

605-B Seismic refraction survey of Pleistocene drainage channels in the lower Great Miami River valley, ohio, by J. S. Watkins and A. M. Spieker. 1971.

605-C Effects of increased pumping of ground water in the Fairfield-New Baltimore area (Hamilton County), Ohio--A prediction by analog-model study, by A. M. Spieker. 1968 .

605-D Future development of the ground-water resources in the lower Great Miami River valley, Ohio--Problems and alternative solutions, by A. M. Spieker. 1968. 
650-B Correlation of carbonate rock units in northwest ohio by natural gamma logging, by S. E. Norris and

R. E. Fidler. 1969.

700-D The effect of stream discharge on streambed leakage to a glacial outwash aquifer, by $S$. E. Norris, in Geological Survey Research 1970, Chapter D, p. D262-D265. 1970 .

750-B Availability of ground water from limestone and dolomite aquifers in northwest ohio and its relation to geologic structure, by S. E. Norris and R. E. Fidler, in Geological Survey Research 1971, Chapter B, p. B229-B235. 1971 .

750-C Carbonate equilibria distribution and its relation to an area of high ground-water yield in northwest ohio, by S. E. Norris and R. E. Fidler, in Geological Survey Research 1971, Chapter C, P. C202-C206. 1971.

750-D Resistivity and neutron logging in silurian dolomite of northwest Ohio, by L. M. MacCary, in Geological Survey Research 1971, Chapter D, p. D190-D197. 1971.

813-A Summary appraisals of the Nation's ground-water resources-Ohio Region, by R. M. Bloyd, Jr. 1974.

813-J Summary appraisals of the Nation's ground-water resources-Great Lakes Region, by W. G. Weist, Jr. 1978 .

\section{Water-Supply Papers}

334

The Ohio valley flood of March-April, 1913, including comparisons with some earlier floods, by A. H. Horton and H. J. Jackson. 1913.

800 The floods of March 1936--Part 3, Potomac, James, and upper Ohio Rivers, by N. C. Grover, with a section area, Butler and Hamilton Counties, Ohio, by F. H. Klaer, Jr., and D. G. Thompson. 1948.

838 Floods of Ohio and Mississippi Rivers, January-February 1937, by N. C. Grover, with a section on flood deposits of the Ohio River, January-February 1937, by G. R. Mansfield. 1938 .

869 Flood of August 1935 in the Muskingum River basin, Ohio, by C. V. Youngquist and W. B. Langbein. 1941.

999 Ground-water resources of the Cincinnati area, Butler and Hamilton Counties, Ohio, by F. H. Klaer, Jr., and D. G. Thompson. 1948 . 
1460-E Geological and geophysical study of the preglacial Teays valley in west-central Ohio, by S. E. Norris and H. C. Spicer. 1958 .

1619-A Hydrogeology of a spring in a glacial terrane near Ashland, Ohio, by S. E. Norris. 1963.

1750-A Floods of January-February 1959 in Ohio and adjacent states, by E. L. Hendricks. 1964 .

1798-I Fluvial sediment in Hocking River subwatershed 1 (North Branch Hunters Run, Hocking County), Ohio, by R. F. Flint. 1972 .

1808 Ground-water resources of the Dayton area (Montgomery County), Ohio, by S. E. Norris and

A. M. Spieker. 1966.

1840-A Floods of March 1964 along the Ohio River, by

H. C. Beaber and J. O. Rostvedt. 1965.

1859-C Analysis of water quality of the Mahoning River in Ohio, by G. A. Bednar, C. R. Collier, and W. P. Cross. 1968 .

1872 Hydrogeology of the Scioto River valley near Piketon (Pil:s rounty), Ohio, by S. E. Norris and R. E. Fidler. 1969 .

1893

2045

2220

Potential development and recharge of ground water in Mill Creek valley, Butler and Hamilton Counties, Ohio, based on analog model analysis, by R. E. Fidler. 1970.

$2275 \quad$ National water summary, 1984.

\section{Bulletins}

1133-A Geology and hydrology of the Piqua area (Mmami County), Ohio, by S. E. Norris and A. M. Spieker. 1961.

\section{Circulars}

Water resources of the Mahonmng River basin, Ohio, with special reference to the Youngstown area, by W. P. Cross, M. E. Schroeder, and S. E. Norris. 1952. 
Water resources of the Wheeling-Steubenville area, West Virginia and Ohio, by R. C. Smith, W. L. Doll, and Garland Stratton. 1955.

418

526

546

719

Floods of January-February 1959 in Ohio, by W. P. Cross and H. P. Brooks. 1959.

Stream quality in Appalachia as related to coal-mine drainage, 1965, by J. E. Biesecker and J. R. George. 1966.

Time of travel of water in the Great Miami River, Dayton to Cleves, Ohio, by D. P. Bauer. 1968.

The National Stream Quality Accounting Network (NASQAN)-Some questions and answers, by J. F. Ficke and R. O. Hawkinson. 1975.

\section{Journal of Research of the U.S. Geological Survey}

Norris, S. E., 1974, Regional flow system and ground-water quality in western Ohio: U.S. Geological Survey Journal of Research, v. 2, no. 5, p. 527-531.

\section{Hydrologic Investigations Atlases}

40

43

44

45

46

47

Floods at Mount Vernon (Knox County),

Floods at Springfield (Clark County), Ohio, in 1913 and 1959, by G. W. Edelen, Jr., F. H. Ruggles, Jr., and W. P. Cross, 1961

Floods at Newark (Licking County), Ohio, by G. W. Edelen, Jr., F. H. Ruggles, Jr., and W. P. Cross. 1962 (revised 1964).

Floods at Chillicothe (Ross County), Ohio, by G. W. Edelen, Jr.,F. H. Ruggles, Jr., and W. P. Cross. 1964 .

Floods at Zanesville (Muskingum County), Ohio, by G. W. Edelen, Jr., F. H. Ruggles, Jr., and W. P. Cross. 1964 .

Floods at Fremont (Sandusky County), Ohio, by G. W. Edelen, Jr., F. H. Ruggles, Jr., and W. P. Cross. 1962 .

Floods at Circleville (Pickaway County), Ohio, by G. W. Edelen, Jr., F. H. Ruggles, Jr., and W. P. Cross. 1964 . 
Floods at Barberton (Summit County), Ohio, by G. W. Edelen, Jr., F. H. Ruggles, Jr., and W. P. Cross. 1962 .

Floods at Canton (Stark County), Ohio, by G. W. Edelen, Jr., W. P. Somers, and W. P. Cross. 1962.

Floods at Warren (Trumbull County), Ohio, by G. W. Edelen, Jr., F. H. Ruggles, Jr., and W. P. Cross. 1963.

Floods at Columbus (Franklin County), Ohio, by G. W. Edelen, Jr., F. H. Ruggles, Jr., W. P. Somers, and W. P. Cross. 1962 .

Floods on Crab Creek at Youngstown (Mahoning County), Ohio, by G. W. Edelen, Jr., W. P. Cross, and W. P. Somers. 1963.

Water resources of the Appalachian Region, Pennsylvania to Alabama, by W. J. Schneider and others. 1965.

Ground-water resources of the Appalachian region, by G. G. Wyrick. 1968 .

Floods at Amesville (Athens County), Ohio, by R. I. Mayo and E. E. Webber. 1969.

Floods at Jackson (Jackson County), Ohio, by E. E. Webber and R. I. Mayo. 1968.

Hydrogeology of the Berea and Cussewago Sandstones in northeastern Ohio, by J. L. Rau. 1969.

Saline ground-water resources of Ohio, by A. C. Sedam and R. B. Stein. 1970.

494 Hydrogeology of the Pottsville Formation in northeastern Ohio, by A. C. Sedam. 1973.

\section{Miscellaneous Investigations Series}

Glacial map of Ohio, by R. P. Goldthwait, G. W. White, and J. L. Forsyth. 1961 (revised in part, 1967). 


\section{Hydrologic Unit Map}

U.S. Geological Survey, 1974, Hydrologic unit map of Ohio. An overprint of the 1:500,000 scale state base map. No contours. Sheet is 36 by 40 inches. 1951 base, drainage modified in 1974. This map and accompanying table show hydrologic units that are basically hydrographic in nature. The Cataloging Units shown supplant those previously used by the U.S. Geological survey in its Catalog of Information on Water Data (1966-72).

\section{Open-File Reports of the U.S. Geological Survey}

Open-file reports are available for inspection at the Columbus, Ohio and Reston, Virginia offices of the U.S. Geological Survey. For information about purchasing these reports, contact Books and Open-File Reports, U.S. Geological Survey, Box 25425, Federal Center, Denver, CO 80225, telephone (303) $236-7476$.

\section{Unnumbered Open-File Reports}

Anttila, P. W., 1970, A proposed streamflow program for Ohio. Cross, W. P., 1967, Flood of July 12, 1966, in the vicinity of Sandusky (Huron County), Ohio.

Deutsch, Morris, and Wallace, J. C., 1966, Six illustrations showing water-resources information on Maumee River basin, Ohio.

Feulner, A. J., 1960, The ground-water resources of Champaign County, Ohio.

Mayo, R. I., Webber, E. E., and Ellis, D. W., 1971, Floods of July 4-8, 1969, in north-central Ohio.

U.S. Geological Survey, 1961-64, Surface-water records of Ohio (published annualiy).

---- 1964, Water-quality records of Ohio.

---- 1965-74, Water-resources data for Ohio--Part 1, Surfacewater records; Part 2, Water-quality records (published annually).

Webber, E. E., and Mayo, R. I., 1970, Flood of July 5, 1969, in the vicinity of Wooster (Wayne County), Ohio.

---- 1971, Low-flow study for southwest Ohio streams. 
Numbered Open-File Reports

76-768 Floods in Ohio--magnitude and frequency, by E. E. Webber and W. P. Bartlett, Jr. 1976.

77-399 Hydraulic analysis, Mad River at State Highway 41, Springfield, Ohio, by R. I. Mayo. 1977.

78-684 Hydrologic environment of the silurian salt deposits in parts of Michigan, Ohio, and New York, by S. E. Norris. 1978.

79-269 The Silurian salt deposits in eastern Lake, northwestern Ashtabula, and northeastern Geauga Counties, Ohio, by S. E. Norris. 1978.

81-343 Hydrology of Area 4, Eastern Coal Province, Pennsylvania, Ohio, and West Virginia, by D. K. Roth, M. J. Engelke, $\mathrm{Jr} .$, and others. 1981.

81-350 Hydraulic analysis, Paint Creek at State Route 772, Chillicothe, Ohio, by R. I. Mayo and W. P. Bartlett, Jr. 1981 .

81-409 Assessment of water quality in streams draining coalproducing areas in Ohio, by C. L. Pfaff, D. R. Helsel, D. P. Johnson, and C. G. Angelo. 1981.

81-414 Flood of August 20, 1979, on a tributary of Chickamauga Creek, near Gallipolis, Ohio, by R. I. Mayo and E. E. Webber. 1981.

81-815 Hydrology of Area 7, Eastern Coal Province, Ohio, by M. J. Engelke, Jr., D. K. Roth, and others. 1981.

81-913 Ground-water hydrology of strip-mine areas in eastern Ohio, by J. O. Helgesen and A. C. Razem. 1981.

81-919 Ground-water quality in the vicinity of landfill sites, southern Franklin County, Ohio, by J. T. de Roche and A. C. Razem, 1981 .

81-1105 Floodflow characteristics related to channel geometry in Ohio, by E. E. Webber and J. W. Roberts. 1981.

81-1195 Low-flow characteristics of Ohio streams, by D. P. Johnson and K. D. Metzker. 1981.

82-109 Potential impacts of a proposed reservoir on hydrologic and water-quality conditions in Little Rush Creek watershed, Fairfield County, Ohio, by Janet Hren and R. L. Jones. 1982 . 
82-170 Water resources of the Black Hand Sandstone Member of the Cuyahoga Formation and associated aquifers of Mississippian age in southeastern Ohio, by S. E. Norris and G. C. Mayer. 1982 .

83-217 Drift mine reclamation in Big Four Hollow near Lake Hope Ohio--A preliminary data report, by V. E. Nichols. 1983.

83-681 Guidelines for use of water-quality monitors, by A. B. Gordon and M. S. Katzenbach. 1983.

84-233 Hydrology of Area 11, Eastern Coal Province, Ohio, Kentucky, and West Virginia, by D. K. Roth and S. C. Cooper. 1984 .

84-249 Chemical and biological quality of selected lakes in Ohio, 1978 and 1979, by C. G. Angelo and J. D. Youger. 1985.

84-470 Preliminary report on a study to establish flood volumes of small rural streams in Ohio -- Methods, site selection, and data base, by J. M. Sherwood. 1985.

84-619 Literature review and need for additional study of surface-water quality in the Cuyahoga Valley National Recreation Area, Ohio, by C. J. Oblinger Childress. 1984.

84-824 Low-flow data for selected partial-record stations in Ohio, by R. R. Schwartz. 1985.

85-099 Occurence of uranium in ground water in the vicinity of the U.S. Department of Energy Feed Materials Production Center, Fernald, Ohio, by A. C. Sedam. 1984 .

85-194 Preliminary evaluation of magnitude and frequency of floods in selected small drainage basins in Ohio, by J. R. Kolva. 1985 .

85-552 Sedimentation and water quality in the West Branch Shade River basin, Ohio, 1984 water year, by C. J. Oblinger Childress and R. L. Jones. 1985.

85-574 Water-quality data-collection activities in colorado and Ohio: Phase I--Inventory and evaluation of 1984 programs and costs, by Janet Hren, T. H. Chaney, J. M. Norris, and C. J. Oblinger Childress. 1985.

85-639 Offstream water withdrawals by theremoelectric powerplants and public water supplies in Ohio. 1982, by Michael Eberle and J. A. McClure. 1986.

86-308 Water-Resources Activities in Ohio, 1986, by S. M. Hindall. 1986 . 


\section{Water-Resources Investigations Reports \\ of the U.S. Geologial Survey}

Reports in this series are available for inspection at the Columbus, Ohio, and Reston, Virginia offices of the U.S. Geological Survey. Information about purchasing these reports may be obtained from the District Chief, Water Resources Division, in Columbus.

17-73 Availability of water from limestone and dolomite aquifers in southwest Ohio and the relation of water quality to the regional flow system, by S. E. Norris and R. E. Fidler. 1973.

18-75 Digital model simulation of the glacial-outwash aquifer at Dayton, Ohio, by R. E. Fidler. 1975.

76-50 Time of travel of solutes in selected reaches of the Sandusky River basin, Ohio, 1972 and 1973, by A. O. Westfall. 1976 .

77-23 Time of travel of solutes in the Tuscarawas River basin, Ohio, August and September 1974, by A. O. Westfall and E. E. Webber. 1977.

77-76 Water quality of the glacial-outwash aquifer in the Great Miami River basin, Ohio, by K. F. Evans. 1977.

77-105 Limnology of selected lakes in Ohio, 1975, by R. L. Tobin and J. D. Youger. 1977.

78-109 Chemical and biological quality of selected lakes in Ohio, 1976 and 1977, by R. L. Tobin and J. D. Youger. 1979 .

79-17 Water-quality assessment of Rattlesnake Creek watershed, Ohio, by K. F. Evans and R. L. Tobin. 1979.

80-28 Ground-water conditions in Geauga County, Ohio, 1978, by V. E. Nichols. 1980 .

80-56 A model for flow through a glacial-outwash aquifer in southeast Franklin County, Ohio, by E. J. Weiss and A. C. Razem. 1980 .

81-17 Water use in Ohio, 1975, by R. M. Hathaway and Michael Eberle. 1981.

82-4019 Model modifications for simulation of flow through stratified rocks in eastern Ohio, by J. 0 . Helgesen, S. P. Larson, and A. C. Razem. 1982.

82-4044 Flood of June 13-15, 1981, in the Blanchard River basin, northwestern Ohio, by E. E. Webber. 1982. 
83-4022 Simulations of nonsteady flow in a glacial-outwash aquifer, southern Franklin County, Ohio, by

A. C. Razem. 1983.

83-4130 Effects of relocating State Route 151 on the flood profiles of Conotton Creek and its tributaries between Bowerston and Scio, Ohio, by W. P. Bartlett, Jr., and others. 1984 .

83-4155 Ground-water hydrology before, during, and after coal strip mining of a small watershed in Coshocton County, Ohio, by A. C. Razem. 1983.

83-4192 Measurement of the reaeration coefficients of the North Fork Licking River at Utica, Ohio, by radioactive tracers, by Janet Hren. 1983.

83-4215 Ground-water hydrology and quality before and after strip mining of a small watershed in Jefferson County, Ohio, by A. C. Razem. 1984 .

84-4024 Water use in Ohio, 1980, by Michael Eberle and J. A. McClure. 1984 .

84-4117 A statistical approach to evaluate the relation of coal mining, land reclamation, and surface-water quality in Ohio, by Janet Hren, R. S. Wilson, and D. R. Helsel. 1984 .

84-4139 Determination of reaeration coefficients for ohio streams, by Janet Hren. 1984 .

84-4179 Effects of surface coal-mine reclamation on stream quality in a small watershed near Nelsonville, southeastern Ohio, by S. M. Hindall. 1984.

84-4212 Classification of stream basins in southeastern Ohio according to extent of surface coal mining, by C. J. ObIinger Childress. 1985.

84-4238 Water quality of a stream-aquifer system, southern Franklin County, Ohio, by J. T. de Roche and

A. C. Razem. 1984 .

84-4276 Flood-profile analysis, Big Darby Creek at State Route 762, Orient, Ohio, by W. P. Bartlett, Jr., and J. M. Sherwood. 1984 .

84-4314 Chemical and isotopic characteristics of brines from three oil- and gas-producing formations in eastern Ohio, with applications to the geochemical tracing of brine sources, by K. J. Breen, C. G. Angelo, R. W. Masters, and A. C. Sedam. 1985. 
84-4336 Contributions of suspended sediment by highway construction and other land uses to the olentangy River, Columbus, Ohio, by D. R. Helsel. 1985.

85-4034 Ground-water quality and geochemistry of aquifers associated with coal in the Allegheny and Monongahela Formations, Southeastern Ohio, by A. C. Razem and A. C. Sedam. 1985 .

85-4060 Surface-water quality of coal-mine lands in Raccoon Creek basin, Ohio, by K. S. Wilson. 1985 .

85-4072 Cost effectiveness of the stream-gaging program in ohio, by H. L. Shindel and W. P. Bartlett, Jr., 1985.

85-4175 Estimating flood peaks from channel characteristics in Ohio, by D. K. Roth. 1985.

85-4197 Evaluation of the effects of coal-mine reclamation on water quality in Big Four Hollow near Lake Hope, Southeastern Ohio, by V. E. Nichols. 1985.

85-4205 Effects of surface coal mining and reclamation on ground water in small watersheds in the Allegheny Plateau, Ohio, by Michael Eberle and A. C. Razem. 1985.

85-4215 Estimating annual suspended-sediment loads in the northern and central Appalachian coal region, by G. F. Koltun. 1985 .

85-4222 Hydrogeology and effects of landfills on groundwater quality, southern Franklin County, Ohio, by J. T. de Roche. 1985.

86-4108 Changes in ground-water quality resulting from surface coal mining of a small watershed in Jefferson County, Ohio, by Janet Hren. 1986. 
Publications of the Ohio Department of Natural Resources, Division of Water, Prepared by or in Cooperation with the U S. Geological Survey

These reports may be obtained from the Chief, Division of Water, who can furnish a more complete list of reports of the Ohio Department of Natural Resources, or they may be consulted in the offices of the Chief, Division of Water, or of the District Chief, Water Resources Division, U.S. Geological Survey, at the address given in this report.

Archer, R. J., 1960, Sediment discharge of Ohio streams during floods of January-February 1959: Miscellaneous Report 13 .

Cross, W. P., 1961, Floods of January-February 1959 in Ohio: Bulletin 35 .

--- 1963, Low-flow frequencies and storage requirements for selected Ohio streams: Bulletin 37.

---- 1964, Floods of March 1963 in Ohio: Bulletin 38.

---- 1964, Floods of March 1964 in Ohio: Bulletin 39.

---- 1965, Low-flow frequency and storage-requirement indices for Ohio streams: Bulletin 40 .

1966, Flood of July 23, 1965, in the vicinity of Hillsboro (Highland County), Ohio: Miscellaneous Report 16.

- - 1967, Drainage areas of Ohio streams, supplement to Gazetteer of Ohio streams: Inventory Report $12 \mathrm{a}$.

---- 1968, Flow duration of Ohio streams, based on gagingstation records through 1965: Bulletin 42 .

Cross, W. P., and Hedges, R. E., 1959, Flow duration of Ohio streams: Bulletin 31.

Cross, W. P., and Mayo, R. I., 1969, Floods in Ohio, magnitude and frequency--Supplement to Bulletin 32 (Cross and Webber, 1959): Bulletin 43.

Cross, W. P. and Webber, E. E., 1950, Ohio streamflow characteristics--Part 2, Water supply and storage requirements: Bulletin 13.

---- 1959, Floods in Ohio--Magnitude and frequency: Bulletin 32.

Cummins, J. W., and Sanderson, E. E., 1947, The water resources of Tuscarawas County, Ohio: (Ohio Water Resources Board) Bulletin 6 . 
Dove, G. D., 1960, Water resources of Licking County, Ohio: Bulletin 36.

---- 1961, A hydrologic study of the valley-fill deposits in the Venice area (Butler County), Ohio: Technical Report 4.

Hubble, J. H., and Collier, C. R., 1960, Quality of surface waters in Ohio, 1946-58: Inventory Report 14.

Raser, Paul, and Harstine, L. J., 1965, Ground-water levels in Ohio, October 1959-September 1964: Bulletin 41.

Lamar, W. L, and Schroeder, M. E., 1951, Chemical character of surface waters in Ohio, 1946-50: Bulletin 23.

Norris, S. E., 1959, The water resources of Madison County, Ohio: Bulletin 33 .

- - 1959, Vertical leakage through till as a source of recharge to a buried-valley aquifer at Dayton (Montgomery County), Ohio: Technical Report 2.

Norris, S. E., Cross, W. P., and Goldthwait, R. P., 1948, The water resources of Montgomery County, Ohio: (Ohio Water Resources Board) Bulletin 12.

---- 1950, The water resources of Greene County, Ohio: Bulletin 19.

Norris, S. E., Cross, W. P., Goldthwait, R. P. and Sanderson, E. E., 1952, The water resources of Clark County, Ohio: Bulletin 22.

Ohio Department of Natural Resources, Division of Water, 1970, Ground water for planning in northwest Ohio--A study of the carbonate rock aquifers: Inventory Report 22 .

Schaefer, E. J., White, G. W., and Van Tuyl, D. W., 1946, The ground-water resources of the glacial deposits in the vicinity of Canton (Stark County), Ohio: (Ohio Water Resources Board) Bulletin 3.

Schmidt, J. J., 1958, The ground-rater resources of Franklin County, Ohio: Bulletin 30 .

Smith, R. C., and White, G. W., 1953, The ground-water resources of Summit County, Ohio: Bulletin 27.

walton, w. C., 1953, The hydraulic properties of a dolomite aquifer underlying the village of Ada (Bardin County), Ohio: Technical Report 1.

walton, W. C., and Scudder, G. D., 1960, Ground-water resources of the valley-rain deposits in the Fairborn area (Greene County), Ohio: Technical Report 3. 
Winslow, J. D., White, G. W., and Webber, E. E., 1953, The water resources of Cuyahoga County, Ohio: Bulletin 26.

\section{Other Publications}

Address inquiries about availability of these reports and paperz to the publishers.

Cross, W. P., 1949, The relation of geology to dry-weather stream flow in Ohio: Transactions of the American Geophysical Union, v. 30 , no. 4 , p. 563-566

Crouch, T. M., Collins, H. R., and Belgesen, J. O., 1980, Abandoned subsurface coal mines as a source of water for coal conversion in eastern Ohio: Ohio Department of Natural Resources Division of Geological Survey Report of Investigations 118.

Deutsch, Morris, Dove, G. D., Jordan, P. R., and Wallace, J. C., 1967, Ground-water distribution and potential in the Ohio River basin: U.S. Army Corps of Engineers, Ohio River Basin Comprehensive Survey, v. VII, app. E--Ground Water.

Dove, G. D., 1960, Drainage of the Teays-stage Mount Vernon and Cambridge Rivers: Ohio Journal of Science, $v .60$, no. 2 , p. 122-124.

-- - 1962, Ground-water resources, in Geology of Fairfield County: Ohio Department of Natural Resources Division of Geological Survey Bulletin 60 .

Feulner, A. J., 1961, Cyclic-fluctuation methods for determining permeability as applied to valley train in the Mad River valley in Champaign County, Ohio: Ohio Journal of Science, v. 6l, no. 2, p. 99-106.

Feulner, A. J., and Hubbll, J. B., 1960, Occurrence of strontium in the surface and ground waters of Champaign County, Ohio: Economic Geology, v. 55, no. 1, p. 176-186.

Hamon, W. R., Haghiri, Faz, and Rnochenmus, Darwin, 1977, Research on the hydrology and water quality of watersheds subjected to surface mining, in Fifth Symposium on surface Mining and Reclamation: Louisville, Ry., National Coal Association and Bituminous Coal Research Inc., p. 37-40.

Bamon, W. R., Bonta, J. V., Haghiri, Faz, and Helgesen, J. 0., 1979, Research on the hydrology and water quality of watersheds subjected to surface mining, I--Premining hydrology and water quality conditions, in Coal Conference and Expo V, Symposium on Surface Coal Mining and Reclamation, Louisville, Ry.: Coal Age, p. 70-98. 
Helgesen, J. O., and Razem, A. C., 1980, preliminary observation of surface-mine impacts on ground water in two small watersheds in eastern Ohio, in Symposium on Surface Mining \#ydrology, Sedimentation and Reclamation: Lexington, Rentucky, University of Rentucky and Institute for Mining and Minerals Research.

Helsel, D. R., and Pfaff, C. L., 1982, Surface-water quality in coal regions of Ohio, in Proceedings, Abandoned Mine Reclamation Symposium, St. Clairsville, Ohio, November 3-5, 1982: Soil Conservation Society of America, All-Ohio Chapter, p. $2 / 1-2 / 7$.

Lamar, W. L., and Collier, C. R., 1956, Suspended sediment characteristics of Ohio streams: Journal of Soil and water Conservation, $\nabla .11$, no. 5, p. 233-237.

Nichols, V. E., 1982, Drift mine reclamation in Big Four Hollow near Lake Hope, Ohio--An overview of preliminary data, in proceedings, Abandoned Mine Reclamation Symposium, St. Clairsville, Ohio, November 3-5, 1982: Soil Conservation Society of America, All-Ohio Chapter, p. 16/1-16/9.

Norris, S. E., 1948, The bedrock surface and former drainage systems of Montgomery County, Ohio: Ohio Journal of Science, v. 48 no. 4 , p. $146-150$.

1951, The bedrock surface and the distribution of the consolidated rocks in Montgomery, Greene, Clark, and Madison Counties, Ohio: Ohio Journal of Science, v. 51, no. 1 , p. $13-15$.

---- 1957, Groundwater investigations--Problems faced by geologists in Ohio: Water Well Journal, July, 1957, p. 1-3.

1957. Characteristics of limestone and dolomite aquifers in western Ohio: Journal of $t^{2}$ ? American Water Works Association, v. 49, no. 4,.. 464-468.

1959a, Minford silt and ground water quality in western Ohio: Journal of the American Water Works Association, v. 51, no. 9, p. 1170-1174,

$1959 \mathrm{~b}$, Buried topography and its relation to an important aquifer in Franklin County, Ohio: Ohio Journal of Science, v. 59 , no. 6 , p. $341-343$.

1967, Effects on ground-water quality and induced infiltration of wastes disposed into the Hocking River at Lancaster (Fairfield County), Ohio: Ground Water, v. 5, no. 3, p. 15-19.

- - 1967, The ground-water situation in Ohio: Ohio Chamber of Comme rce. 
---- 1969, The ground-water situation in Ohio: Ground Water, v. 7 , no. 5 , p. 25-33.

---- 1972, The use of gamma logs in determing the character of unconsolidated sediments and well construction features: Ground Water, v. 10, no. 6, p. 14-21.

---- 1975a, The ground-water situation in the Circleville area (Pickaway County), south-central Ohio: Ohio Department of Natural Resources Division of Geological Survey Report of Investigations 96 .

---- 1975b, Geological structure of near-surface rocks in western Ohio: Ohio Journal of Science, v. 75 , no. 5, p. 225-228.

---- 1976, Change in drawdown caused by enlarging a well in a dolomite aquifer: Ground Water, v. 14, no. 4, p. 191-193.

---- 1979, Hydraulic properties of a limestone-dolomite aquifer near Marion, north-central Ohio: Ohio Department of Natural Resources Division of Geological Survey Report of Investigations 110.

----- 1983a, Aquifer tests and well field performance, Scioto River valley, Ohio; Part I: Ground water, v. 21 , no. 3 , p. 287-92.

---- 1983b, Aquifer tests and well field performance, Scioto River valley, Ohio; Part II: Ground Water, v. 2I, no. 4, p. 438-44.

Norris, S. E., and Eagon, B. B., Jr., 1971, Recharge characteristics of a watercourse aquifer system at Springfield (Clark County), Ohio: Ground Water, v. 9, no. 1, p. 30-4l.

Norris, S. E., and Fidler, R. E., 1966, Use of type curves developed from electric analog studies of unconfined flow to determine the vertical permeability of an aquifer at Piketon (Pike County), Ohio: Ground Water, v. 4, no. 3, p. 43-48.

Razem, A. C., 1982, Comparisons of premining, mining, and postmining ground-water conditions in three small watersheds in eastern Ohio: Geological Society of America Abstracts with Programs, v. 15, no. 7 .

--- 1983, Ground-water monitoring of three small surface-mined watersheds of eastern Ohio (abstract): Ground Water Monitoring Review, v. 3, no. 1, p. 153.

Razem, A. C., and Belgesen, J. O., 1981, Preliminary observation of surface-mine impacts on rround water in two small watersheds in eastern Ohio (abs' dct), in Indiana Water Resources Second Annual Symposium, spencer, Indiana. 
Schneider, W. J., 1957, Relation of geology to streamflow in the Upper Miami basin: Ohio Journal of Science, v. 57 no. 1, p. $11-14$.

White, G. W., 1951, Illinoian and Wisconsin drift of the southern part of the Grand River lobe in eastern Ohio: Geological Society of America Bulletin, v. 62, no. 9, p. 967-977.

---- 1953, Sangamon soil and early wisconsin loesses at Cleveland (Cuyahoga County), Ohio: American Journal of Science, v. 251 , no. 5, p. 362-368. 